\title{
Efficiency of Persulfate Activated by UV Irradiation in the Presence of Granular Activated Carbon for Removal of Methylene Blue Dye from
}

\section{Aqueous Solution}

\author{
Abdolmotaleb Seidmohammadi ${ }^{1}$, Hasan Zoolghadrnasab ${ }^{2}$, Faezeh Nouri $^{3}$, Darya Yavari ${ }^{3}$ Fatemeh Asadi $^{3}$ \\ 1. Associate Professor, Department of Environmental Health Engineering, School of Public Health, Hamadan University of \\ Medical Sciences, Hamadan, Iran. ORCID ID: 0000-0001-8197-1324 \\ 2. M.S.C., Department of Environmental Health Engineering, School of Public Health, Hamadan University of Medical \\ Sciences, Hamadan, Iran. ORCID ID: 0000-0003-2955-7390 \\ 3. B.Sc., Department of Environmental Health Engineering, School of Public Health, Hamadan University of Medical \\ Sciences, Hamadan, Iran. ORCID ID: 0000-0003-2975-3324 \\ 4. Ph. D Student, Student Research Committee, Department of Environmental Health Engineering, School of Public Health, \\ Hamadan University of Medical Sciences, Hamadan, Iran., (Corresponding Author), Email: f_asadi56@yahoo.com, Tel: \\ 0831-8281992, ORCID ID:0000-0002-8119-2555
}

\begin{abstract}
Background and Aim: Dyes are one of the most important pollutants in textile wastewater (TWW). Use of advanced oxidation processes (AOPs) as an efficient method can be useful for removal of these pollutants from the effluent of textile wastewater. In this study we evaluated the efficiency of the persulfate activation process, using ultraviolet (UV), in the presence of granular activated carbon (GAC) for removal of methylene blue dye (MBD). Also, we studied the effect of operating parameters on the dye removal.

Materials and Methods: This experimental study was performed in a pilot-scale batch photoreactor. The effect of operating parameters including solution $\mathrm{pH}$ (between 3 and 9), dosage of granular activated carbon $(0.6-5 \mathrm{mg} / \mathrm{L})$, persulfate concentration $(0.2-2 \mathrm{mmol} / \mathrm{L})$, initial concentration of methylene blue dye $(50-400 \mathrm{mg} / \mathrm{L})$, and contact time (2-30 minutes) were evaluated. The final concentration of methylene blue dye was measured by using DR6000 device. Mineralization of the process, in optimal conditions, was determined by measuring COD and TOC.
\end{abstract}

Results: The highest efficiency of the process for removal of methylene blue dye (99\% dye removal at an initial concentration of $50 \mathrm{mg} / \mathrm{L}$ ) was observed at $\mathrm{pH}=3$, granular activated carbon dose of $1 \mathrm{~g} / \mathrm{L}$, optimal persulfate concentration of $1 \mathrm{mmol} / \mathrm{L}$, and after a 20-minute contact time. The removal rates of COD and TOC were $71 \%$ and $69.9 \%$, respectively, and the decomposition rate of methylene blue dye was based on the first-order reaction $\left(\mathrm{R}^{2}=0.99\right)$.

Conclusion: Considering the results of this study, the combined process had a significant efficiency to remove methylene blue dye and can be used as an efficient method for removal of the dye from the effluent of textile wastewater.

Keywords: Methylene blue dye, Ultraviolet, Persulfate, Activated granular carbon

Received: Jan 7, 2020

Accepted: Oct 3, 2020

How to cite the article: Abdolmotaleb Seidmohammadi, Hasan Zoolghadrnasab, Faezeh Nouri, Darya Yavari, Fatemeh Asadi. Efficiency of persulfate activated by UV irradiation in the presence of granular activated carbon for removal of methylene blue dye from aqueous solution. SJKU. 2020;25(3):52-70.

Copyright $\odot 2018$ the Author (s). Published by Kurdistan University of Medical Sciences. This is an open access article distributed under the terms of the Creative Commons Attribution-Non-Commercial License 4.0 (CCBYNC), where it is permissible to download, share, remix, transform, and buildup the work provided it is properly cited. The work cannot be used commercially without permission from the journal 
كارايى فر آيند برسولفات فعالشده با امواج فرابنفى در حضور كربن فعال تر انوله در حذف

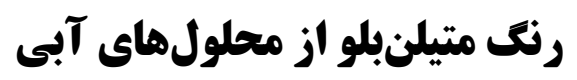

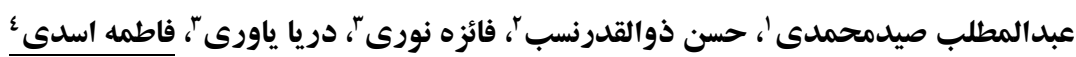

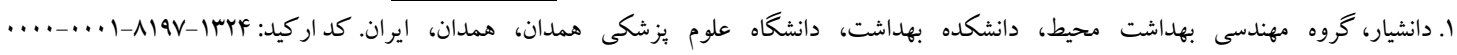

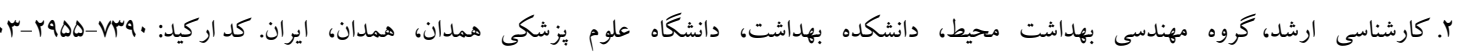

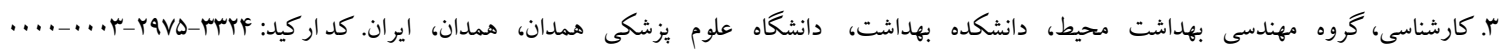

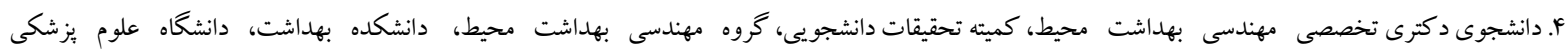

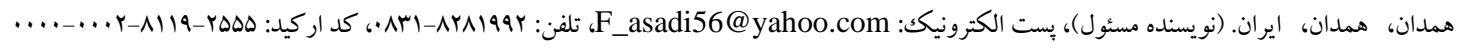

جكکبه زمينه و هدف: رنغكها از مهمترين آلايندهاى موجود در فاضلاب صنايع نساجى مىباشند. استفاده از فر آيندهاى اكسيداسيون

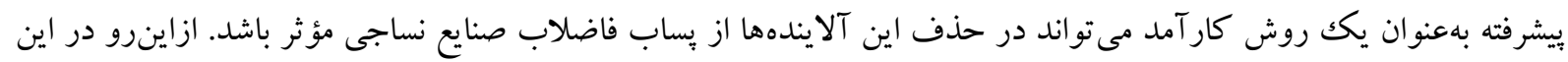

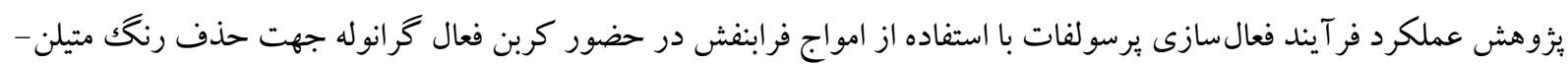

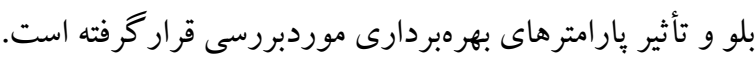

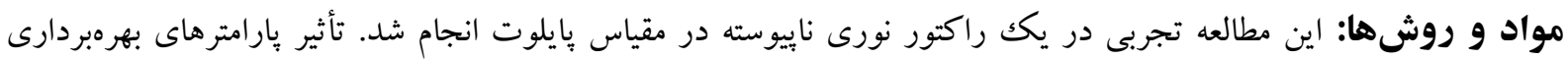

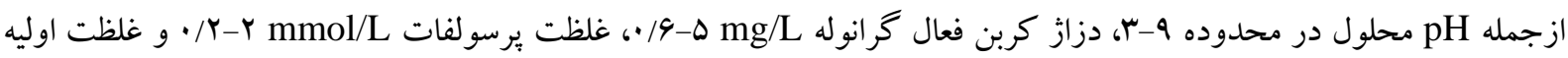

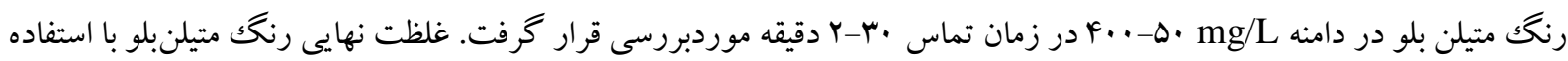
از دستكاه DR-6000 اندازهيرى شد. معدنى سازى فر آيند در شرايط بهينه با اندازهگيرى

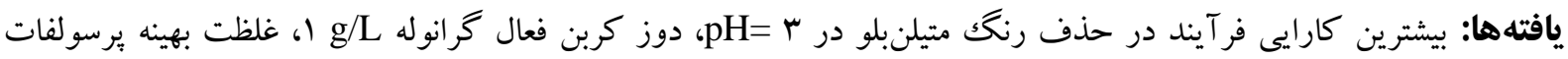

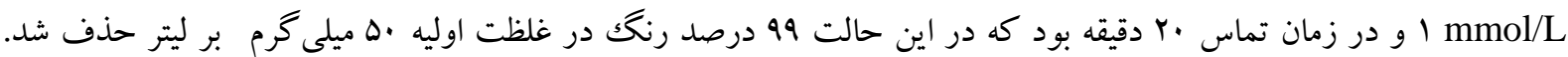

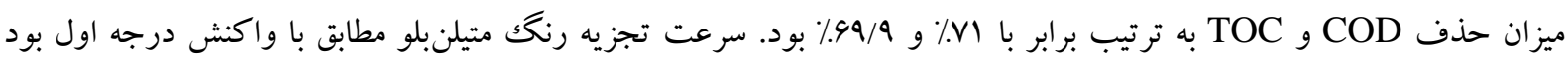
.$\left(\mathrm{R}^{2}=\cdot / 99\right)$

نتيجه كيرى: بر اساس نتايج حاصل از اين يزوهش فر آيند تلفيقى موردنظر كارايى قابلتوجهى در حذف رنكك متيلنبلو داشته و

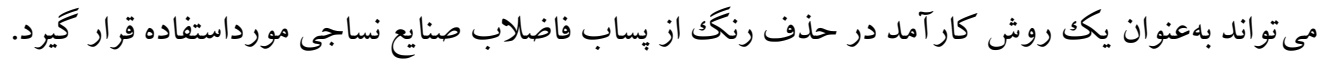

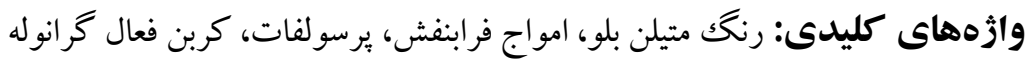

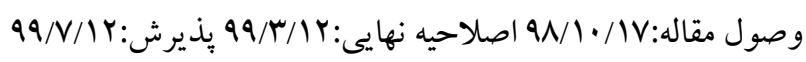


كمرنغك هاى مصنوعى، سيستمهاى متداول تصفيه بيولوزيك فاضلاب به دليل نياز به زمان طولانى داراى

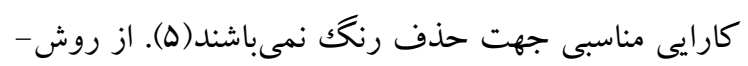

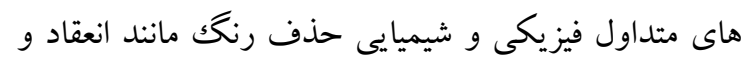

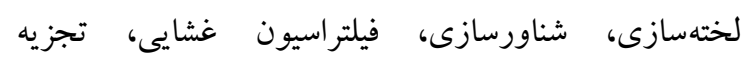

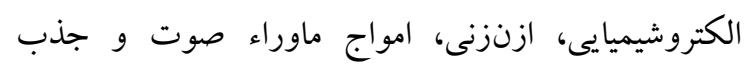

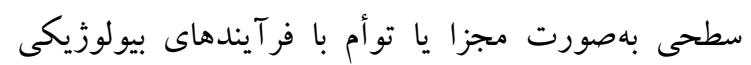

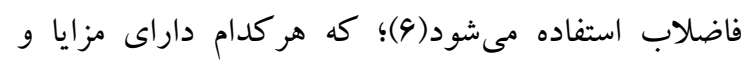

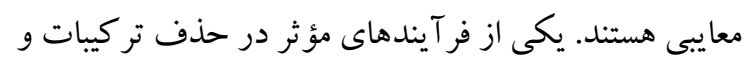
مواد آلى سمى و غيرقابل تجزيه بيولوزيكى فر آيندهاى

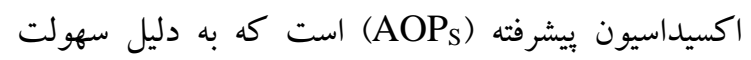
كاربرد، اقتصادى بودن، كارايى بالا و عدم توليد مقادير زياد

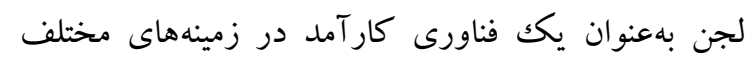

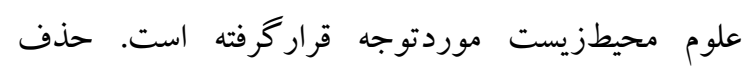
آلايندهها در فرآيند اكسيداسيون بيشرفته بر بايه توليد راديكال هاى آزاد هيدرو كسيل ( ) باقدرت اكسيداسيون بالا بوده كه بسيارى از تركيبات

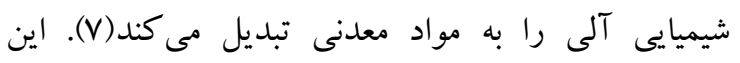

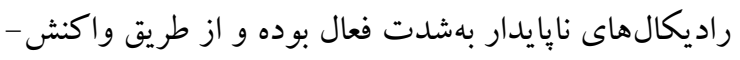
هاى شيميايى در محل توليد مىشوند. راديكالهاى آزاد

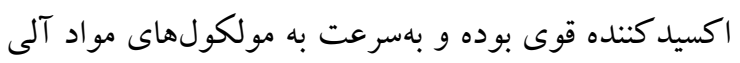

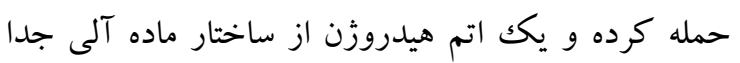

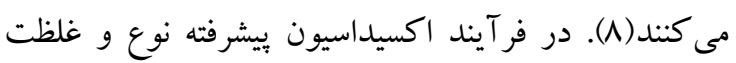

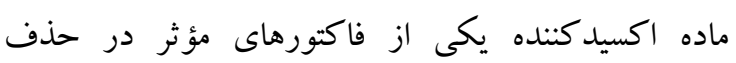
تركيبات آلى است. برسولفات يكى از عوامل اكسيداسيون دو الكترونى است كه در حضور فعال كنندها به رئ راديكال

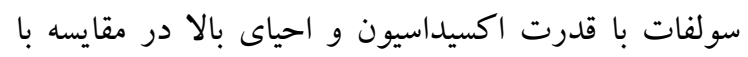

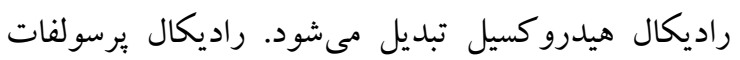

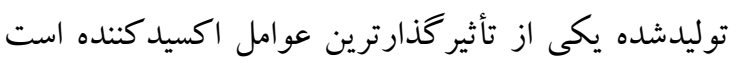

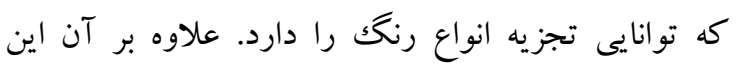

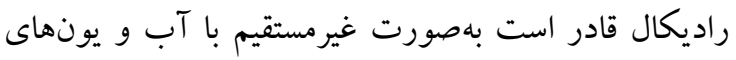
هيدر كسيل وارد واكنش شده و راديكال هيدرو كسيل توليد
مقدمه

امروزه با توسعه صنعت و يِيشرفت تكنولوزى مبتنى بر دانش

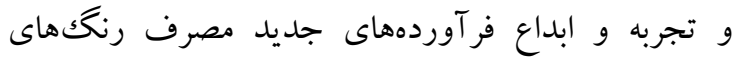

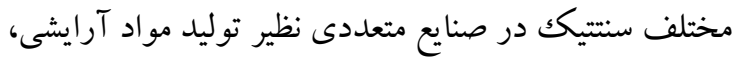
جرم، كاغذ و صنايع نساجى افزايشيافته است. افزايش

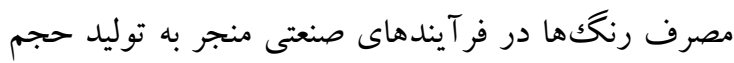

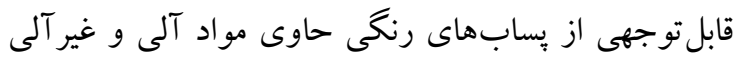

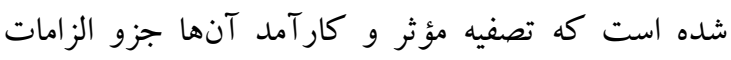

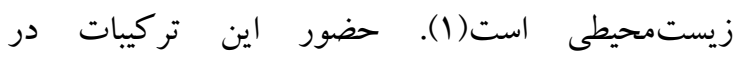

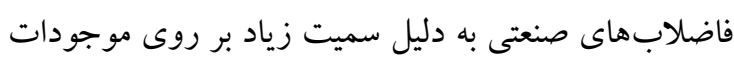
آبزى، اختلال در كارايى سيستمهاى متداول تصفيه فاضلاب و زيباشناختى محيط موردتوجه جدى محققين قرارگرفته

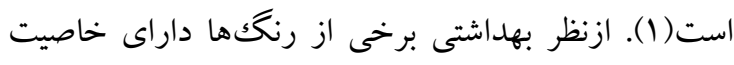
سرطانزايى و جهشزايى بوده و مىتوانند موجبات ايجاد

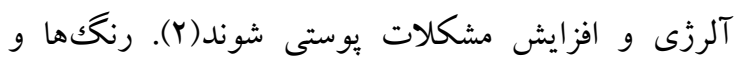

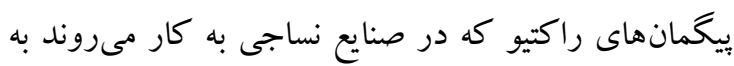

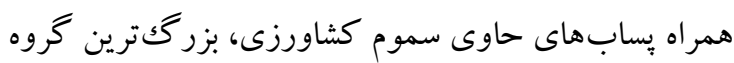

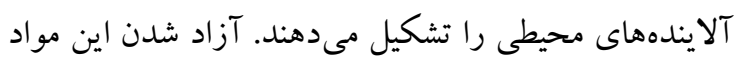
در طبيعت تهديد جدى براى اكوسيستمهاى آبى به شمار

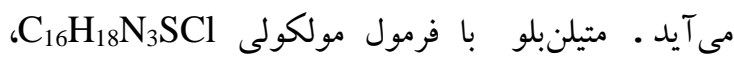

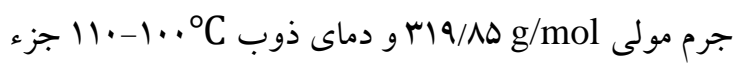

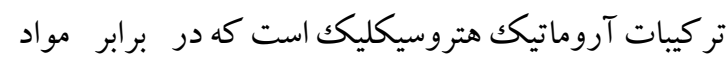
شيميايى، گرما، نور و حتى تجزيه بيولوزيكى مقاوم

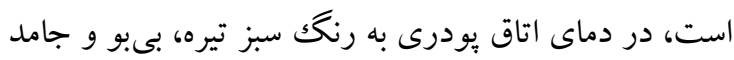

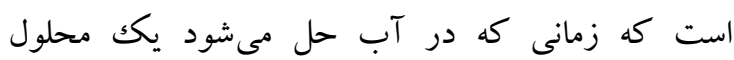
آبىرنگك به دست مى آيد. شكل آبدار آن داراى مانى

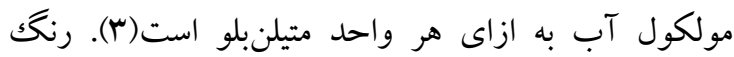

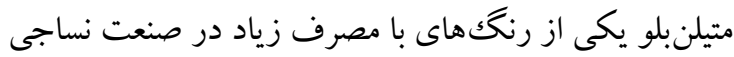

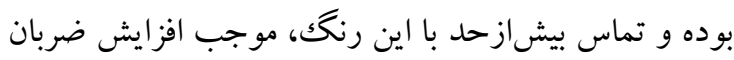
قلب، استفراغ، شوكى، سيانوز، زردى، نكروز بافت در انسان

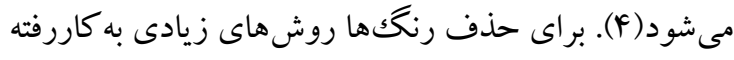

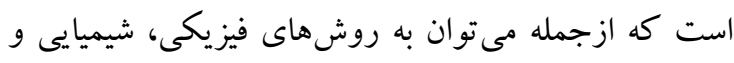

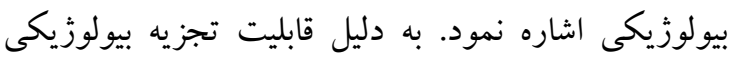


جاذب خوبى براى حذف آلايندها از آب و فاضلاب است؛ ولى نقش آن بهعنوان كاتاليست بهخوبى شناخته

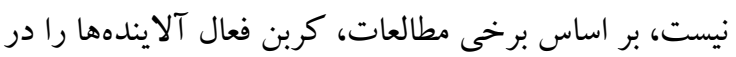

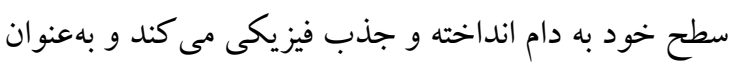

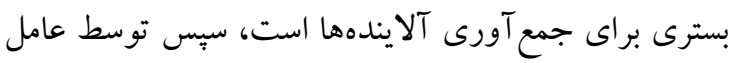

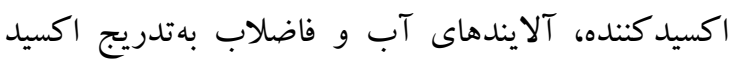
مى شوند و كربن فعال دوباره احياشده و وارد جرخه واكنش

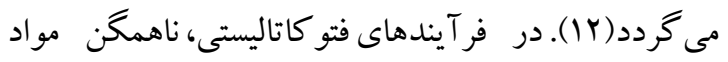
واكنش در يك فاز نمىباشند و بدرداحتى در محيط

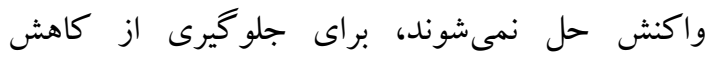

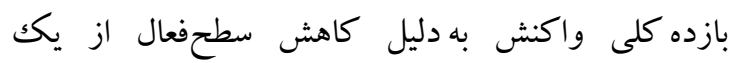
كاتاليست استفاده مىشود. تركيب برسولفات با ظرفيت

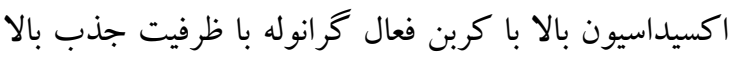
در فر آيندهاى اكسيداسيون بيشرفته، اثر سينرزيستى است كه نتيجه آن توليد يونهاى هيدروكسيل بيشتر و تجزيه و معدنى سازى بهتر مواد آلى و نيز كاهش مصرف برسولفات

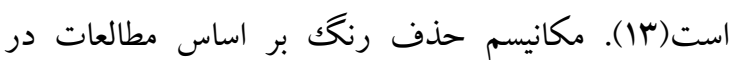
واكنشهاى فوتو كاتاليستى طى جند مرحله صورت مى -

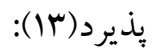

جذب نور توسط كاتاليست طى رابطه ا:

$G A C+h v \rightarrow \mathrm{e}_{\mathrm{CB}}{ }^{-}+\mathrm{h}_{\mathrm{VB}^{+}}$

Y ) سبس توليد راديكالهاى سولفات تحت تأثير

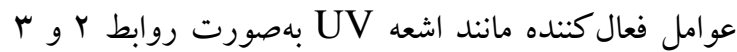

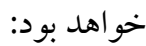

$\mathrm{S}_{2} \mathrm{O}_{8}^{-2}+h v_{v b}^{+} \rightarrow 2 \mathrm{SO}_{4}^{\bullet}$

$\mathrm{S}_{2} \mathrm{O}_{8}^{-2}+$ catalyst $^{+} \rightarrow \mathrm{SO}_{4}^{\cdot}+$ catalyst $^{(n+1)}+\mathrm{SO}_{4}^{-2}(\mathrm{r}$ r ) ب اكسيداسيون ماده آلى توسط راديكال يرسولفات طى روابط ث)، هو 9:

$R+\mathrm{SO}_{4}^{\bullet} \rightarrow \mathrm{R}^{\bullet}+\mathrm{SO}_{4}^{-2}$
نمايد كه خود عامل مهم در تجزيه رنگكها به شمار

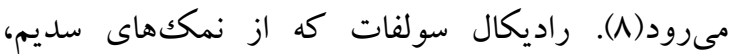

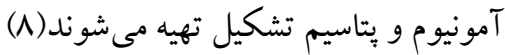

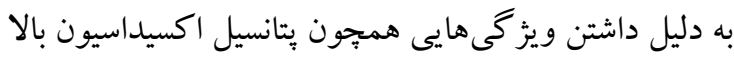
(E = Y/・ V) دماى اتاق، حلاليت بالا و ارزان بودن بهعنوان يكك اكسيد كننده قوى براى حذف آلايندهها مطرح شده است (9). از آنجايى كه واكنشهاى برسولفات در دماى اتاق معمولاً به كندى انجام مى شوند، لذا لازم است كه فعال كرددد (9).

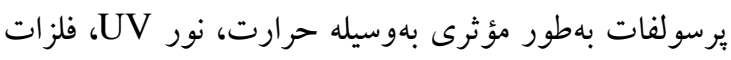
واسطه (Me بمحض فعالسازى برسولفات، باندهاى O-O در ساختار

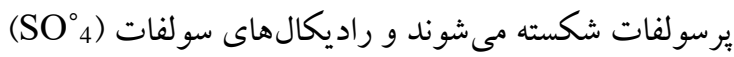

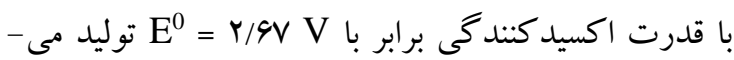

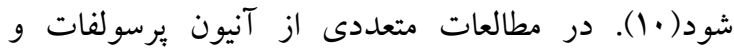

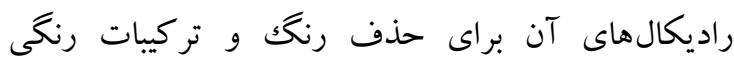

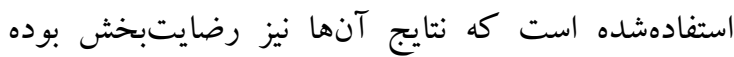
است(11). اكسيداسيون كاتاليزور نورى تكنيك التهايت ييشرفتهاى است كه با استفاده از آن آلايندهاى آلى بهطور كامل تجزيهشده و ازبين مىروند. در

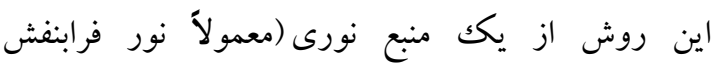
استفاده مىشود. از طرفى تنها تعدادى از مواد (UVV

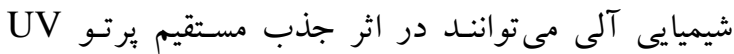
تجزيـه گردند درحالى كه برخى از تر كيبات آلى خطرناك

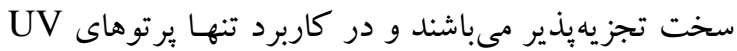

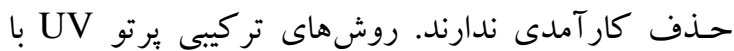
اكسيدكندهها باعث افزايش سرعت و اثربخشى در تجزيه تر كيبات آلى مى گردد(1). كربن فعال به علت مساحت

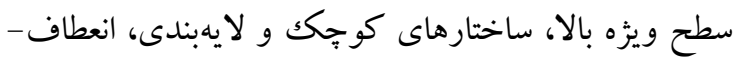

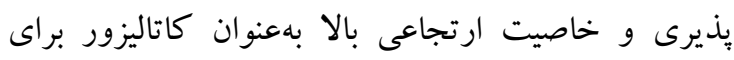

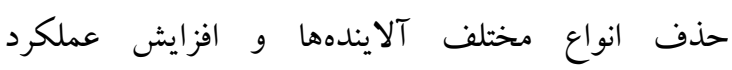
فوتو كاتاليستى موردبر رسى قرار كرفته است(V). 
داخل يك محفظة استيلى و حجم ب ليتر بود. محل انجام

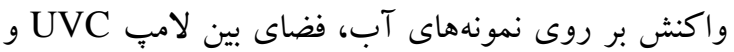

يوشش استيلى بود (شكل (1).
$R+h^{+} \rightarrow R^{+\circ} \rightarrow$ degradation products $(\Delta$

$\mathrm{RCOO}^{-}+h^{+} \rightarrow \mathrm{R}^{\bullet}+\mathrm{CO}_{2}$

استفاده از فرآيند تلفيقى يكى به دليل سادگى، افزايش كارايى حذف مواد آلى، عدم توليد مقادير زياد لجن و لهونى ديخرى به دليل كاهش هزينههـاى مـتبط بسيار مفيد

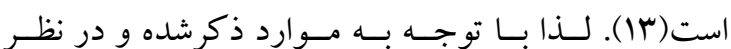

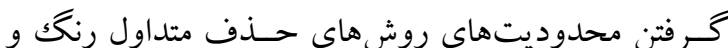
محاسن روشهاى اكسيداسيون وييشـفقته بــا اسـتفاده از يرسولفات و اشعه UV، شامل كوتاه بودن زمان انجام واكنش و نيز عدم توليد محصولات نهايى خطرناك، هدف

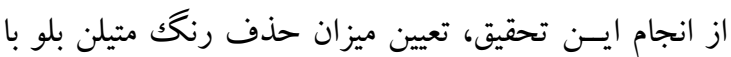

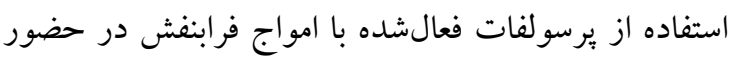

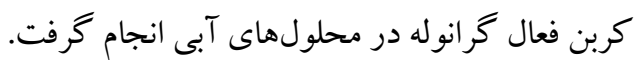

\section{مواد و روشها}

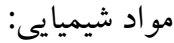
اين ئزوهش يكك مطالعه تجربى-كاربردى است كه در

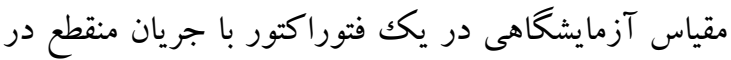

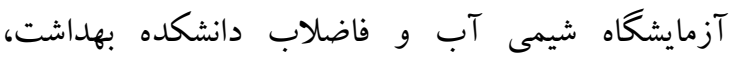
دانشگاه علوم يزشكى همدان انجام شد. صورت بذ بذيرفت.

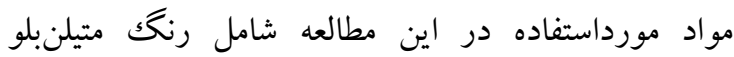
تهيهشده از شركت الوان ثابت واقع در استان همدان، يرسولفات، هيدرو كسيدسديم و اسيدسولفوريكك يكك نرمال از شركت Merck خريدارى شـد. جدول ا و r

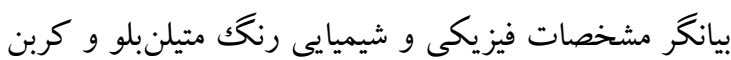

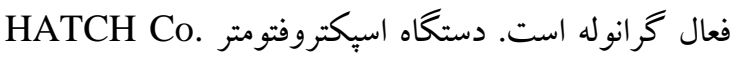

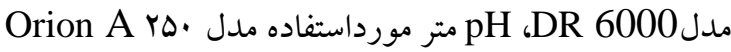
شر كت Hatch مورداستفاده قرار گرفت.

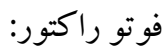

منبع تابش اشعه از يك لامب جيوهاى كمفشار UVC با لوز

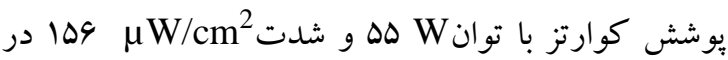


جدول 1. خصوصيات فيزيكى و شيميايى رنك متيلنبلو خريدارى شده

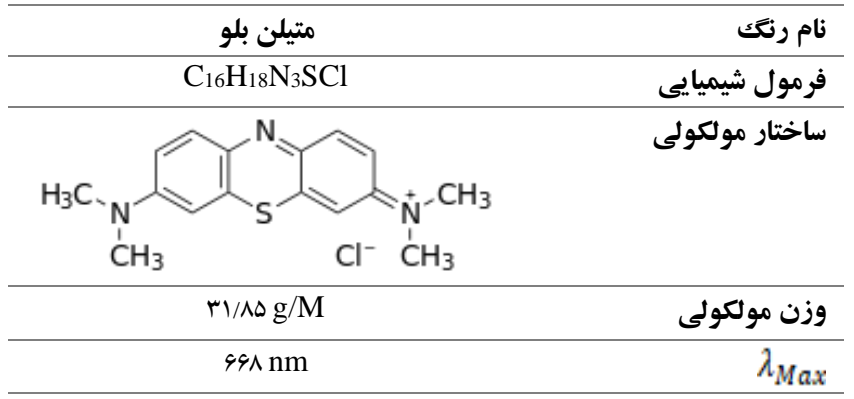

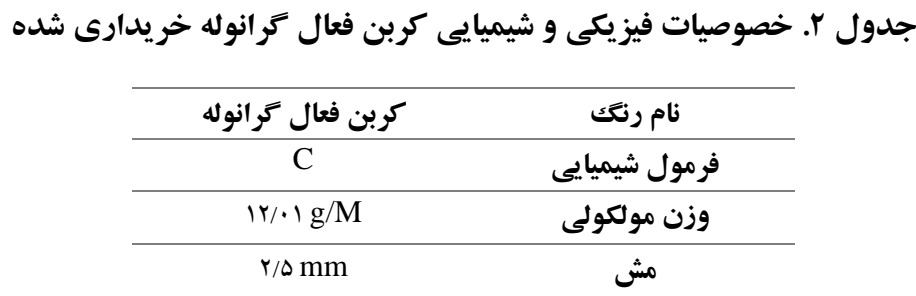

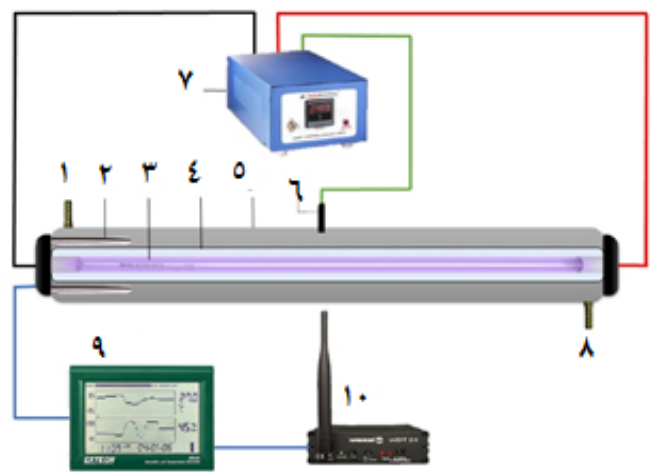

(1) ورودى نمونه

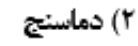

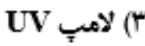
ع) لوله كوارتز

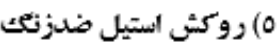

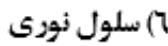

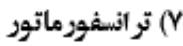

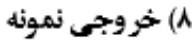

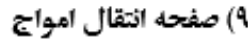

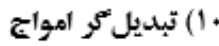

شكل 1. شماتيك راكتور مورداستفاده در اين ثزوهش 


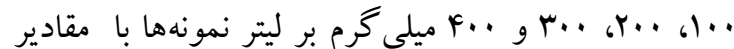
بهينه غلظت كربن فعال گر انوله، برسولفات و pH طى زمان •r دقيقه تحت تأثير امواج فرابنفش قرار كرفت. آناليز نمونهها و معدنى سازى:

بهمنظور تعيين كارايى فر آيند مذكور در فرآيند معدنى سازى بعد از به دست آمدن شرايط بهينه، نمونهها با غلظت

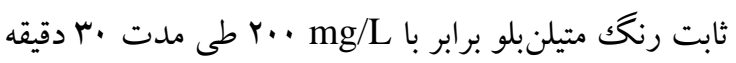
در معرض امواج فرابنفش، كربن فعال گرانوله و يرسولفات قرار داده شد و بر اساس دستورالعملهاى مندرج در كتاب استاندارد متد(IF) در طولموج •90 نانومتر مقدار كاهش COD بررسى شد. بهمنظور اندازهيرى COD، محلولهاى هضم و معرف اسيد طبق دستورالعمل ارائهده در كتاب روش هاى استاندارد براى آزمايش آب و فاضلاب تهيه شد.

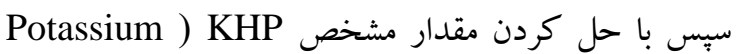

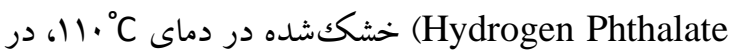
آب مقطر، سرى نمونها با غلظتهاى مشخص COD COD ساخته شد. نمونها جهت هضم در دستگاه

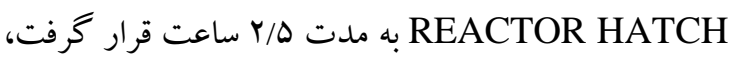
توسط دستخاه اسبكتروفتومتر (DR 6000) در طولموج

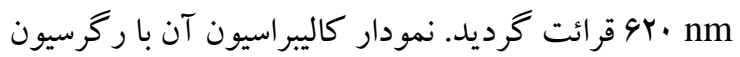
999 • رسم و فرمول نمودار خطى به دست آمد. همجنين تعيين باقيمانده غلظت TOC با استفاده از دستگاه TOC آناليزر مدل elementary ساخت كشور آلمان انجام كرفت. جهت اندازه گيرى غلظت باقيمانده رنگك متيلنبلو از دستگاه استكتروفتومترى 6000 DR شركت استفاده شد. با استفاده از اسكن طولموج، طولموج سو نانومتر كه در آن بيشترين ميزان جذب مشاهده شد انتخاب كرديد. يّ از رسم منحنى استاندارد و قرائت غلظت باقيمانده رنگك متيلنبلو راندمان حذف رنگگ متيلنبلو با استفاده از معادله ا تعيين شد:
در پِايان هر آزمايش نمونهها براى رسوب كاتاليزور در دستخاه سانتريفوز با دور f... rpm قرار كرفت. همجينين بهمنظور اندازهگيرى ميزان كارايى فر آيند در معدنىسازى، مقدار كاهش COD و TOC در شرايط بهينه اندازهگيرى

شد(1) ) (1).

$$
\text { روش انجام فر آيند و متغيرها: }
$$

در تمامى مراحل انجام آزمايشهاى از محلول ذخيره g/L

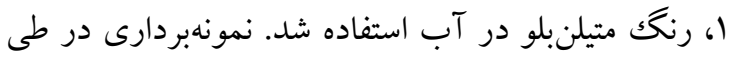
زمانهاى مشخص و در فاصله زمانى ه تا .ب دقيقه انجام كرفت. نمونههاى موردنياز در اين تحقيق بهصورت سنتيكك بود. حجم نمونه استفادهشده در هر مرحله آزمايش ·له سىسى بود. نظر به اينكه جهت انجام اين مطالعه هريك از متغيرها در دامنه موردنظر در ه سطح و 9 زمان مورد آناليز

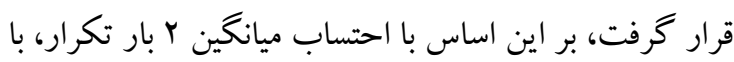
روش فاكتوريل ·11 نمونه، براى تعيين اثر اشعه فرابنفش،

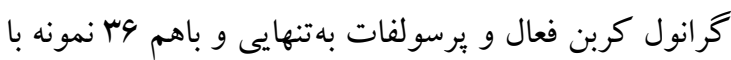
احتساب Y بار تكرار مجموعاً، تعداد كل آزمايشهاى برابر 194 نمونه بود. بهمنظور بررسى تأثير pH بر فرآيند، pH

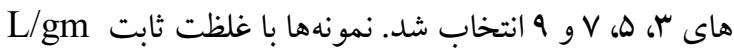

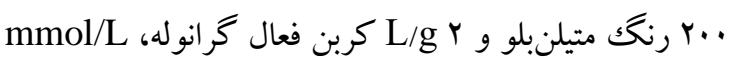
ه/ • برسولفات طى زمان ·ـ دقيقه داخل دستگاه VU قرار كرفت. در تمامى مراحل آزمايش از اسيدسولفوريك و سديم هيدروكسيد / / • نرمال جهت تنظيم pH نمونها استفاده شد(If). جهت تعيين تأثير غلظتهاى مختلف

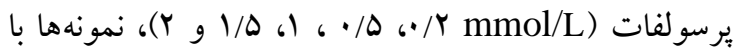

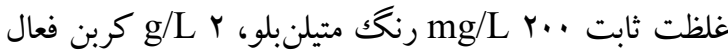
كر انوله و pH بهينه حاصل از مرحله قبل طى زمان ·r دقيقه درون راكتور امواج فرابنفش قرار گرفت. براى تعيين تأثير غلظتهاى مختلف كاتاليزور كربن فعال گرانوله (ه/ g/L/ •،

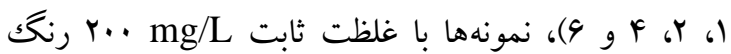
متيلنبلو، يرسولفات و pH بهينه حاصل از مراحل قبل طى زمان ·r دقيقه تحت تأثير امواج فرابنفش قرار كرفت. براى تعيين تأثير غلظتهاى مختلف رنغك متيلن بلو در مقادير ·ه، 
مى گردد(10). در اين مطالعه براى مطالعه سينتيك واكنش از r مدل سينتيك درجه صفر، درجه يكك و درجه دو

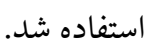

\section{نافته ها}

تأثير تغييرات pH در كارايى فر آيند UV/GAC/S سرعت واكنش هاى شيميايى به pH محيط بستخى داشته و محلول بهطور مستقيم و غيرمستقيم بر اكسيداسيون مواد شيميايى تأثير گذار است(19). در فرآيندهاى اكسيداسيون ييشرفته، تغييرات pH از طريق توليد راديكالهاى متنوع بر ميزان اكسيداسيون مواد آلى تأثير گذار است. نتايج تأثير تغييرات pH محيط در دامنه q-r در شكل Y نشان دادهشه

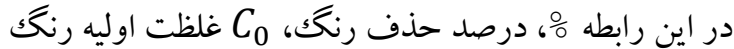
و $C_{t}$ تعيين سينتيك واكنش تجزيه رنگك متيلنبلو در فرآيند

$\mathrm{UV} / \mathrm{GAC} / \mathrm{S}_{2} \mathrm{O}_{8}$ در اين بزوهش سينتيك و واكنش بهمنظور تهيه اطلاعاتى در خصوص عو امل مؤثر بر سرعت واكنش و مكانيسم تبادل واكنشخرها به محصولات با استفاده از سه مدل از واكنشهاى درجه صفر، يكك و دو بهصورت زير محاسبه كرديد(10). سرعت واكنش در سنتيك درجه صفر، مستقل از غلظت ماده اوليه است و طبق رابطه زير تعيين مى گردد:

$R c=\frac{d c}{d t}=K$

سرعت واكنش درجه يكك، مستقيماً متناسب با غلظت مواد

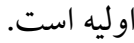

$R c=\frac{d c}{d t}=K C_{t}$ (r

سرعت واكنش در سينتيك درجه Y، متناسب با توان دوم

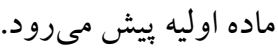

$R c=\frac{d c}{d t}=K C_{t}^{2}$

در اين معادلات: - م إن

Rc سرعت واكنش، Co: غلظت اوليه، Ct: غلظت در زمان K t t معادله خطى بهوسيله ترسيم مقادير غلظت Ct در زمان دست مى آيد. در واكنش درجه يك، از ترسيم در زمان t معادله خطى و در واكنش مرتبه دوم از مقادير 1/Ct شكلهاى مرتبههاى مختلف، شيب منحنى شكل يا مقدار ثابت سرعت واكنش (K) قابلمحاسبه است. ابعاد ضريب سرعت به مرتبه واكنش بستگى دارد. سرعت واكنش داراى آحاد غلظت، آزمان) است. در واكنش درجه صفر ثابت سرعت واكنش برحسب mg/L.min و در واكنشهاى درجه ا و ب به ترتيب برحسب L/min و L/mg.min بيان 


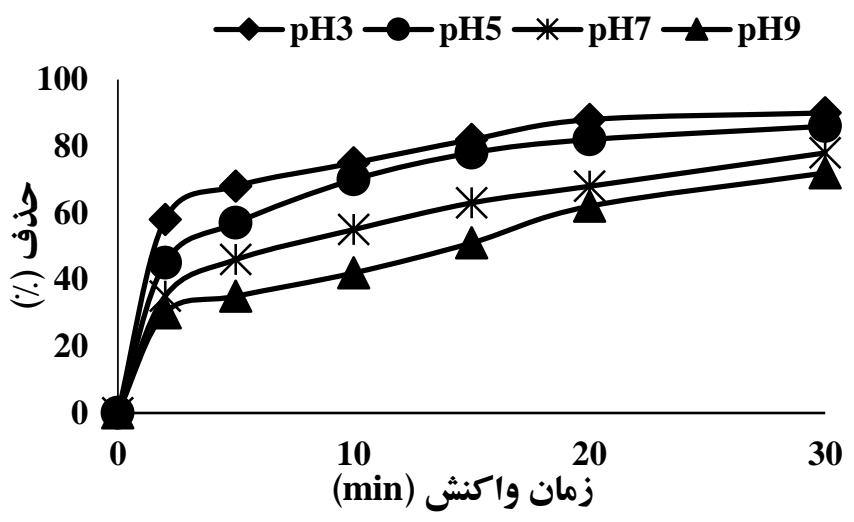

شكل r. تأثير تغيير ات pH محيط در ميزان حذف رنك متيلن مبلو

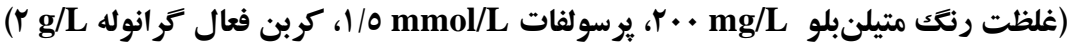

تأثير تغييرات غلظت بيرسولفات در كارايى فرآيند

$\mathrm{UV} / \mathrm{GAC} / \mathrm{S}_{2} \mathrm{O}_{8}$

نتايج تأثير غلظتهاى متفاوت برسولفات در دامنه Y/ • تا ץ

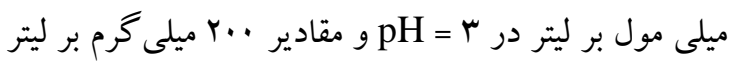

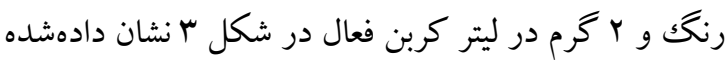

$$
\begin{aligned}
& \text { بر اساس نتايج ارائهده در شكل Y در شرايط اسيدى و در } \\
& \text { pH برابر با ب بيشترين حذف رنغك متيلنبلو مشاهدهشده } \\
& \text { pH است. بر اساس نتايج ارائهشده در شكل Y با افزايش } \\
& \text { محيط راندمان حذف كاهشيافته و در V pH و } 9 \text { به ترتيب }
\end{aligned}
$$

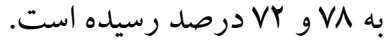

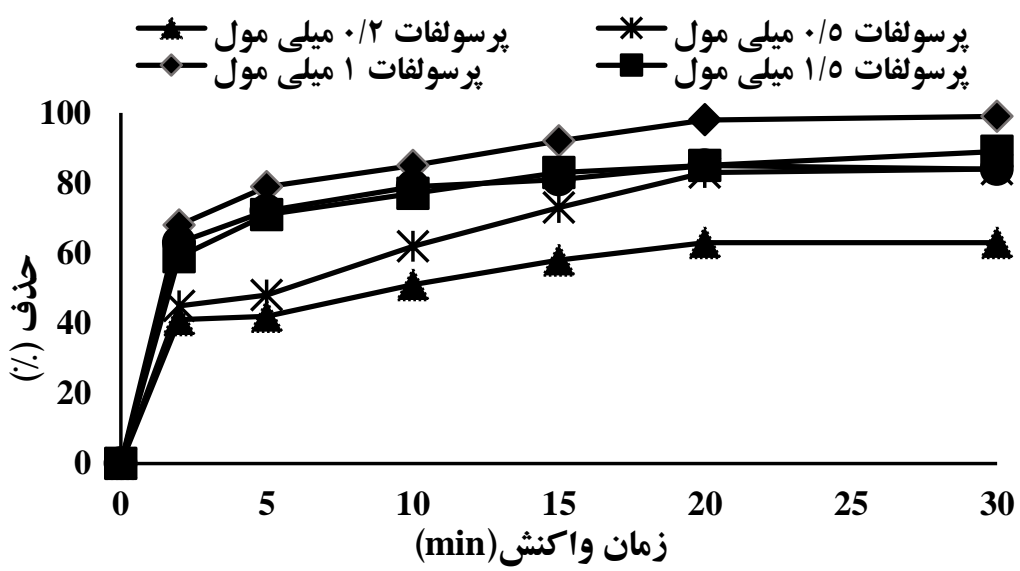

شكل r. تأثير تغييرات غلظت يرسولفات محيط در ميزان حذف رنكى متيلنبلو

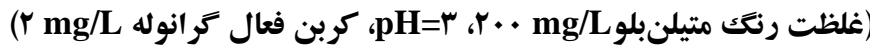




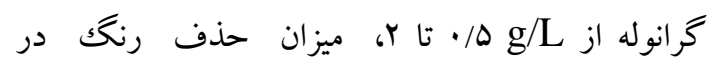

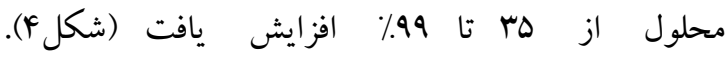

تأثير تغييرات غلظت كربن فعال گرانوله در كارايى فرآيند

$\mathrm{UV} / \mathrm{GAC} / \mathrm{S}_{2} \mathrm{O}_{8}$

بررسى تأثير ميزان دزاز كاتاليزور مورداستفاده در حذف آلاينده نشان داد كه با افزايش كربن فعال

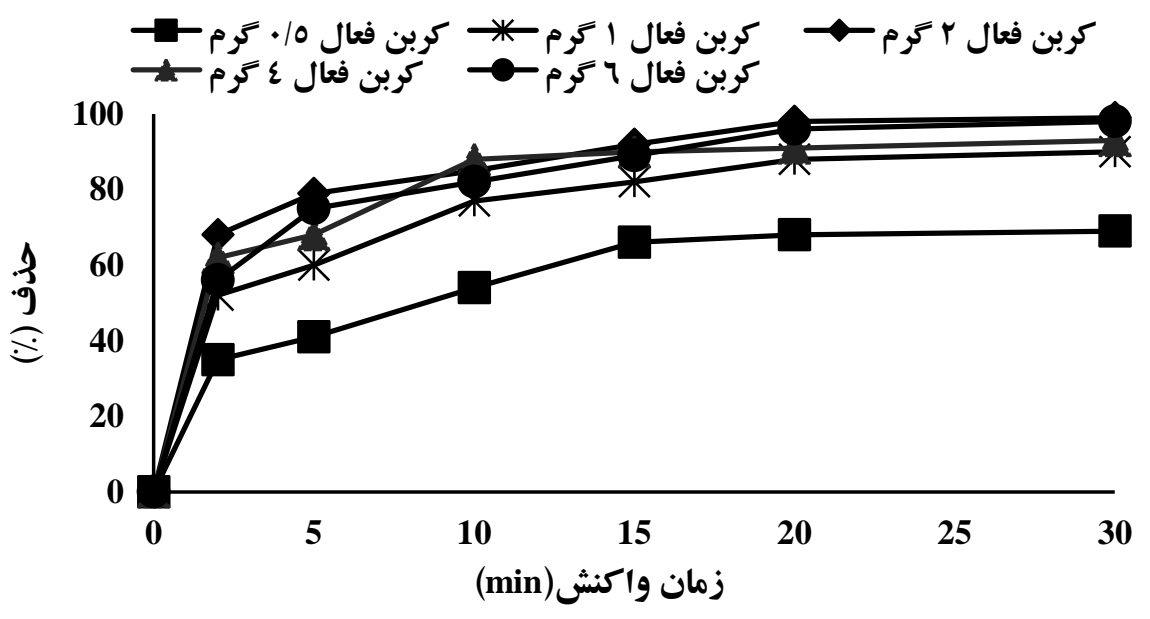

شكل ع. تأثير تغييرات غلظت كربن فعال تر انوله در ميزان حذف رنك متيلنبلو

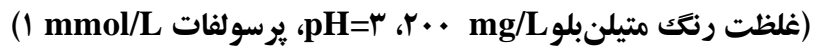

ارائهده در شكل ه، ميزان حذف رنگك در فرآيند تلفيقى موردنظر به غلظت اوليه رنغك متيلنبلو بستخى دارد به-

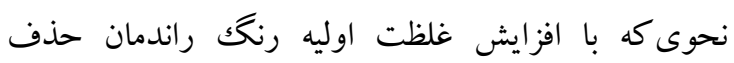
كاهشيافته است. بيشترين كارايى حذف فر فر آيند به ميزان

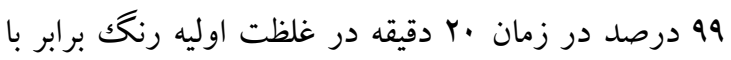

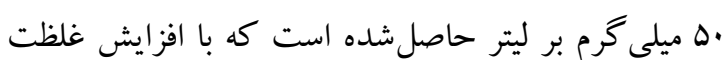

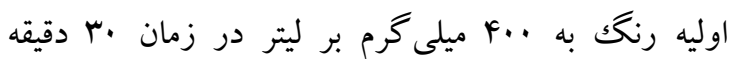
راندمان حذف به VF درصد كاهش يافته است.
تأثير تغيير ات غلظت اوليه رنگك متيلن بلو در كارايى فر آيند $\mathrm{UV} / \mathrm{GAC} / \mathrm{S}_{2} \mathrm{O}_{8}$ فاضلاب صنايع نساجى حاوى غلظتهاى متفاوتى از رنگك

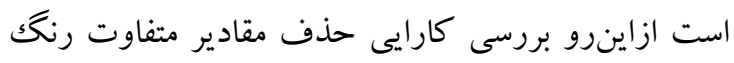
در فر آيند حائز اهميت است. نتايج تأثير غلظتهاى بردئ اوليه

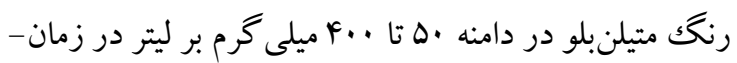
هاى مختلف بهرهبردارى و شرايط بهينه بهرهبردارى

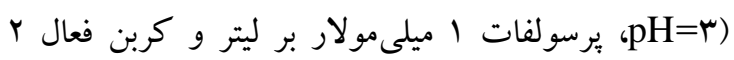
كرم بر ليتر) در شكل ها نشان دادهشده است. بر اساس نتايج 


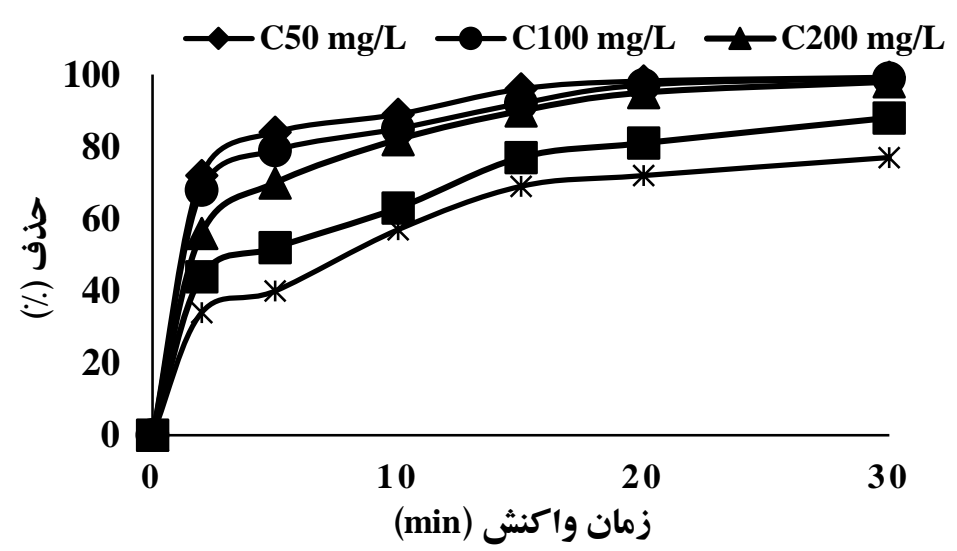

شكل ه. تأثير تغييرات غلظت اوليه رنك متيلنبلو در ميزان حذف آن آن آنال

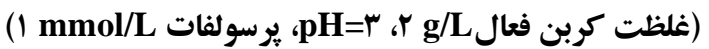

متيلنبلو را در طى زمان ·r دقيقه در شرايط بهينه بهرهتأثير همافزايى مكانيسمها

بردارى حذف نمودهاند.اين در حالى است كه فر آيند تو أم بهنظور تعيين ميزان تأثير هر يك از بارامترهاى مؤثر در

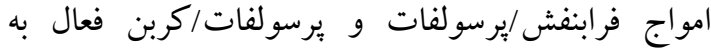
حذف رنغك در غلظت تأثير فر آيندهاى مختلف ازجمله ترتيب VY و VQ Vوصد رنغك را حذف نموده است كه كربن فعال، يرسولفات و اشعه فرابنفش بهصورت مجزاو

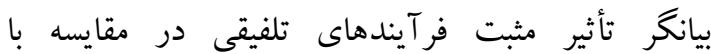
فر آيندهاى تلفيقى امو اج فرابنفش / يرسولفات و يرسولفات فر آيندهاى مجزا بوده است. مقايسه اين نتايج با فرآيند اكربن فعال در شرايط بهينه بهرهبردارى و غلظت اوليه توأم UV/GAC/S

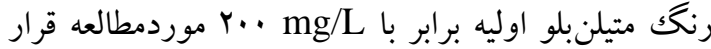
نسبت به فر آيندهاى مورد مطالعه به تنهايى بود، بهنحوى كه

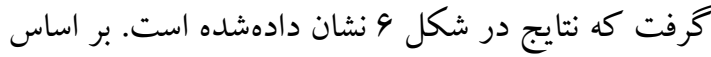
بر اساس ميزان حذف رنگك آنها را بهصورت زير طبقه-

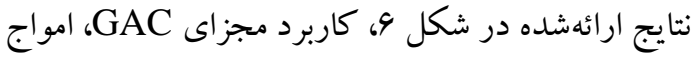

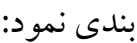
G

GAC $<\mathrm{UV}<\mathrm{S}_{\mathbf{2}} \mathrm{O}_{\mathbf{8}}<\mathrm{UV} / \mathrm{S}_{\mathbf{2}} \mathrm{O}_{\mathbf{8}}<\mathrm{GAC} / \mathrm{S}_{\mathbf{2}} \mathrm{O}_{\mathbf{8}}<\mathrm{UV} / \mathrm{GAC} / \mathrm{S}_{2} \mathrm{O}_{8}$

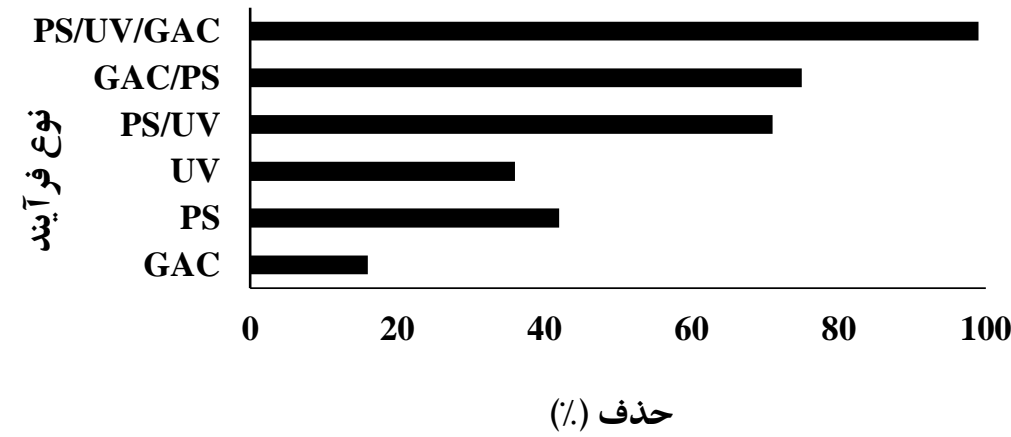

شكل 7. مقايسه حذف رنك متيلنبلو در شرايط بهينه توسط فر آيندهاى مختلف 


\begin{tabular}{|c|c|}
\hline راندمان حذف رنغك در غلظت موردنظر بالغ بر هو درصد & تأثير فرآيند UV/GAC/S $2 \mathrm{I}_{2}$ در فر آيند معدنى سازى: \\
\hline بوده است. آناليزهاى انجامشده در خصوص تغييرات & بر اساس نتايج ميزان تجزيه رنغك متلين بلو بر اساس \\
\hline غلظت TOC نيز بيانحر كاهش غلظت كل كربن آلى به & آزمايش COD كه در شكل V نشان دادهشه است، \\
\hline ميزان 99/9٪ درصد بود (شكل V). جدول ץ مقايسه ميزان & فر آيند تلفيقى موردمطالعه بعد از كذشت زمان ·r دقيقه از \\
\hline فتو كاتاليستى را با مطالعه & انجام فر آيند و در غلظت اوليه رنغك ..ب ميلى گرم بر ليتر \\
\hline 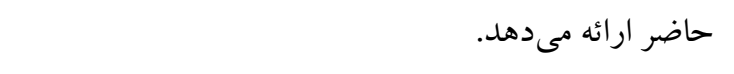 & ا V درصد كاهش COD را سبب شده \\
\hline
\end{tabular}

\begin{tabular}{|c|c|c|c|c|c|}
\hline راندمان حذف & سينتيكك واكنش & درصد & فر آيند & سال & نويسنده \\
\hline رنك متيلبلو (٪) & & معدنى سازى & & & \\
\hline 90 & - & $a r / 4$ & UV بر برولفات & r.19 & (IY) Xiheng zhang \\
\hline $1 \ldots$ & درجه اول & $\Delta N / 1$ & يلاسما - يرسولفات & r.19 & (1A) Guntae Son \\
\hline १८ & درجه اول & - & بر برولفات فعالشده & $r \cdot 1 r$ & $\begin{array}{r}\text { Antoine } \\
\text { Ghauch } \\
\text { (19) }\end{array}$ \\
\hline १^ & درجه اول & ११ & $\begin{array}{l}\text { يُرسولفات/ } \\
\text { UV }\end{array}$ & $r \cdot .9$ & $(r \cdot)$ Mohamed \\
\hline$\Lambda \Delta$ & درجه اول & - & يرسولفات/ FeO & $r .19$ & $\begin{array}{rr}\text { Chang-Mao Hung } & \begin{array}{r}(r I) \\
\end{array}\end{array}$ \\
\hline 99 & درجه اول & GK/VD & $\begin{array}{l}\text { يُرسولفات/ } \\
\text { UV/GAC }\end{array}$ & 1499 & مطالعه حاضر \\
\hline
\end{tabular}

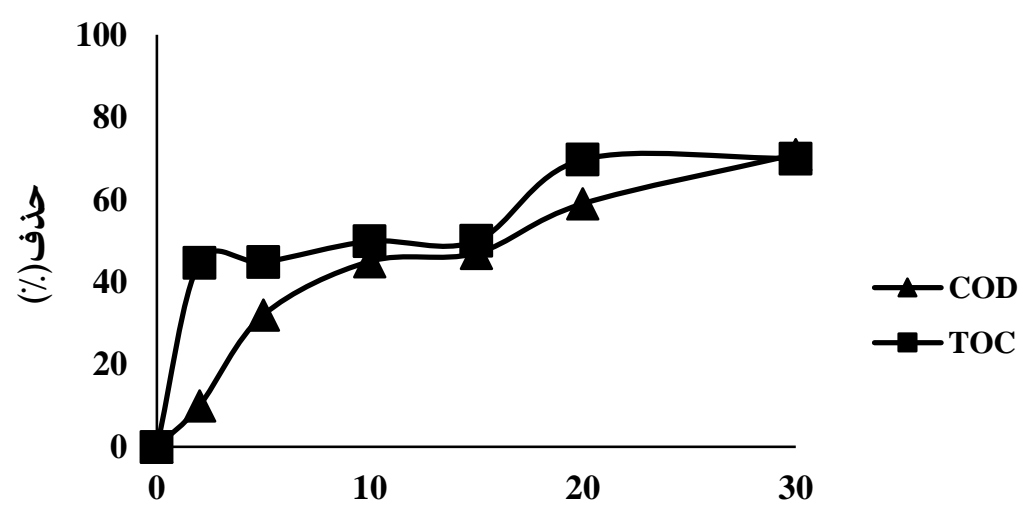

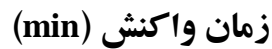

شكل Y. كارايى

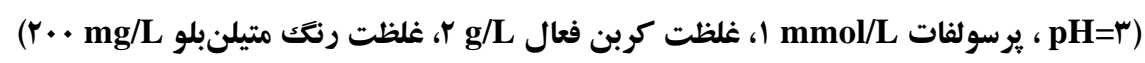


عاو كارآيى فرآيند ِِرسولفات...

همبستخى مطابقت بيشترى با واكنش درجه اول دارد (به دليل مقادير بالاتر R/2)، نسبت به دو مدل ديكر نزديكتر
تعيين سينتيك واكنش تجزيه رنگك متيلنبلو در فرآيند

$\mathrm{UV} / \mathrm{GAC} / \mathrm{S}_{2} \mathrm{O}_{8}$ بر اساس نتايج ارائهده در جدول f و شكله ضريب تجزيه ( 199 / • است كه فر آيند بر اساس ضريب

جدول ع. ضرايب سينتيكى مربوط به حذف رنكى متيلنبلو

\begin{tabular}{|c|c|c|c|c|c|c|}
\hline \multicolumn{3}{|c|}{ ثابت سرعت(K) } & \multicolumn{3}{|c|}{ ضريب تعيين( R } & \multirow{2}{*}{ غلظت اوليه رنك (mg/L) } \\
\hline$r_{\cdot} \cdot$ & $1 \cdots$ & $\Delta \cdot$ & r.. & $1 \cdots$ & $\Delta \cdot$ & \\
\hline$-Y / \Lambda \Delta \Delta \Lambda$ & $-1 / \cdot \Delta q \mu$ & $-\cdot /$ FFEV & •/ATIA & $\cdot / \wedge \Delta \Delta V$ & - /VVDr & صفر \\
\hline.$/ 1119$ & ./ITAV & ./Irra &.$/ 9991$ & $\cdot / 9 \wedge V F$ & $\cdot / 9 \Lambda Y \Lambda$ & اول \\
\hline$\cdot / \cdot \lambda r$ & (1. & $\cdot 1 \cdot 9 \cdot 1$ & $\cdot / A V \Delta \Lambda$ & - ATVG & - MMFY & دوم \\
\hline
\end{tabular}

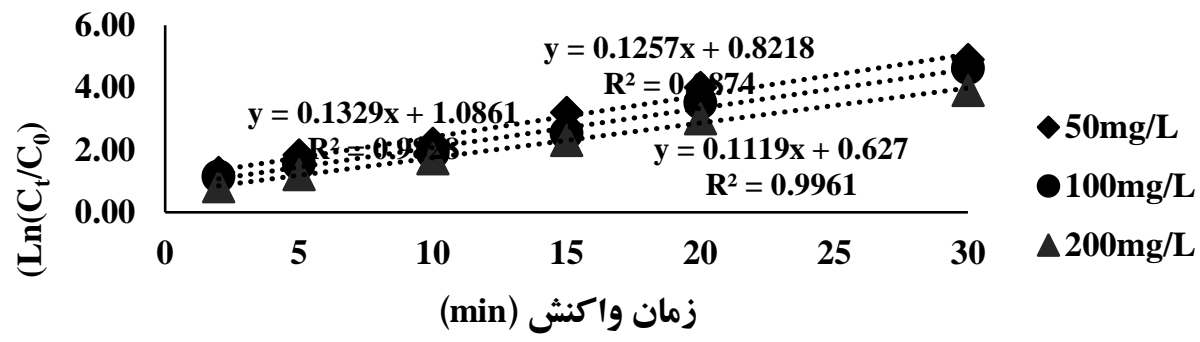

شكل ^. سينتيك واكنش درجه اول حذف رنك متيلن بلو در شرايط بهينه

مىشود كه خود عاملى ديخر براى افزايش حذف رنگك در محيط اسيدى به شمار مىرود (روابط هو 9)(سا). $\mathrm{S}_{2} \mathrm{O}_{8}{ }^{2-}+2 \mathrm{H}_{2} \mathrm{O} \rightarrow \mathrm{HSO}_{4}^{-}+\mathrm{H}_{2} \mathrm{O}_{2}$ $\mathrm{SO}_{4}{ }^{\circ-}+\mathrm{H}_{2} \mathrm{O} \rightarrow \mathrm{H}^{+}+\mathrm{SO}_{4}^{2-}+\mathrm{OH}^{\circ}$ از طرفى علت كاهش راندمان حذف رنگگ را در شرايط قليايى مىتوان اين گونه بيان نمود كه در شرايط قليايى، راديكالهاى سولفات بهصورت رابطه V با آنيونهاى هيدرو كسيل براى توليد راديكالهاى هيدرو كسيل واكنش لئ

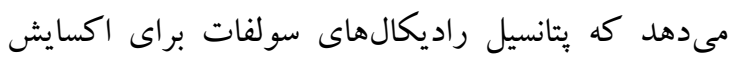

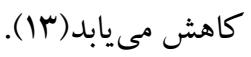

بهمنظور تعيين بهترين محدوده كارايى سيستمها، غلظت هاى مختلف يرسولفات، غلظتهاى اوليه رنخك، غلظتهاى مختلف كربن فعال گر انوله و محدودههاى مختلف pH در زمانهاى مختلف تابش اشعه UV موردمطالعه قرار گرفت. علت كارايى فر آيند در محيط اسيدى را مىتوان اين گونه تفسير نمود كه در شرايط اسيدى توليد راديكال سولفات كه داراى بيشترين يتانسيل اكسيداسيون و احيا نيز است در حداكثر مقدار خود بوده و به همان نسبت قدرت تخريبى رنگ توسط آن افرايش مىيابد. همجنين در اين شرايط هيدروليز برسولفات منجر به توليد براكسيد هيدروزن 
افزايش pH بـ كـاهش توانسايى حسذف توسط

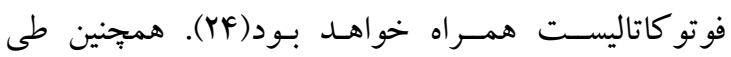

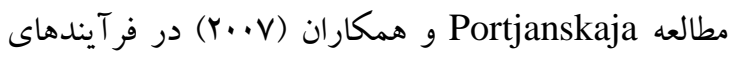

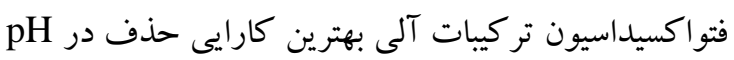
هاى اسيدى اتفاق افتاده است(ه). بر اساس نتايج اين مرحله از انجام آزمايشهاى الفاي با افزايش

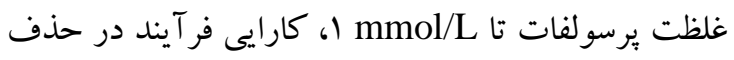

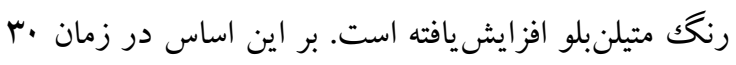

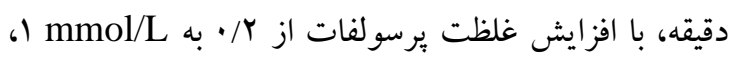
راندمان حذف از أه به 99٪ افز ايشيافته است؛ كه از دلايل آن اين است كه با افزايش غلظت GAC، راديكال

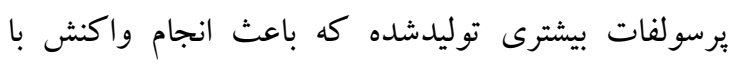

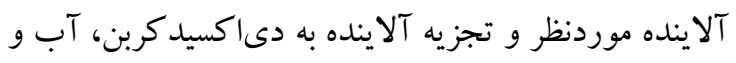

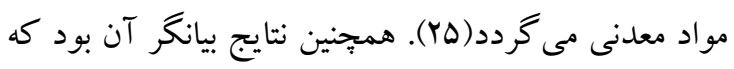

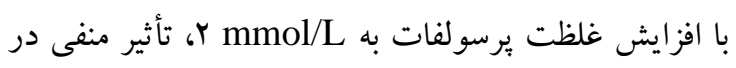

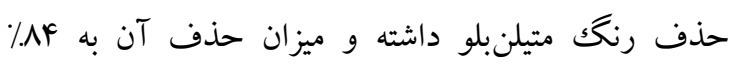

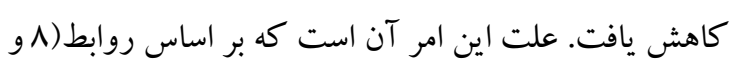

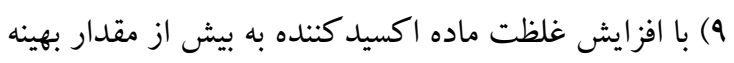

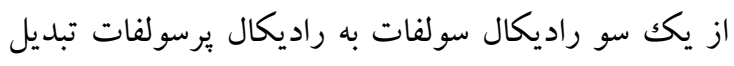

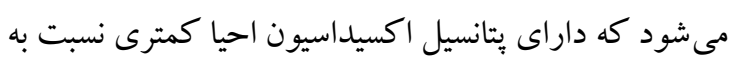

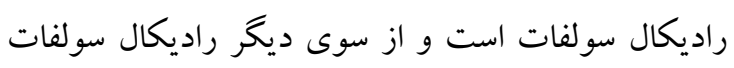

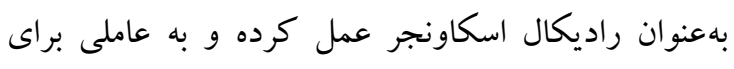

تبديل راديكال سولفات به برسولفات عمل مى كند (Yه). $\mathrm{S}_{2} \mathrm{O}_{8}{ }^{2-}+\mathrm{SO}_{4}^{\bullet} \rightarrow \mathrm{SO}_{4}^{2-}+\mathrm{S}_{2} \mathrm{O}_{8}^{\bullet-}$

$\mathrm{SO}_{4}^{\bullet}+\mathrm{SO}_{4}^{\bullet} \rightarrow \mathrm{S}_{2} \mathrm{O}_{8}^{2-}$

نتايج مطالعه قانعيان و همكاران (1/19) در خصوص حذف رنگك توسط يرسولفات يُتاسيم و نور خورشيد نتايج بيانگر

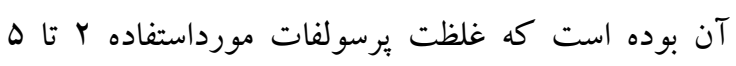

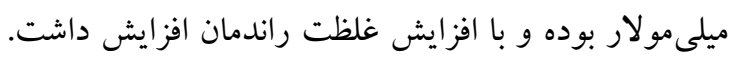

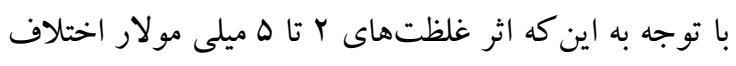
جندانى نداشت براى بررسى از غلظت ب ب ميلى بمولار

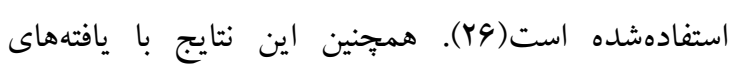

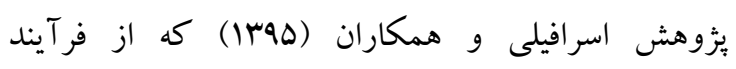

$\mathrm{SO}_{4}{ }^{+}+\mathrm{OH} \rightarrow \mathrm{SO}_{4}^{2-}+\mathrm{OH}$

نتايج ساير مطالعات در اين زمينه نيز بيانخر تأثير گذارى حذف آلايندها با استفاده از فرآيندهاى اكسيداسيون

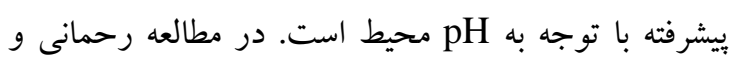

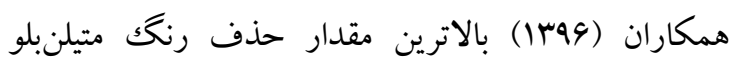

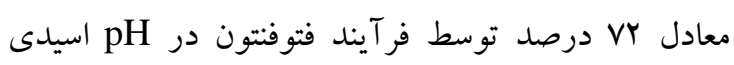

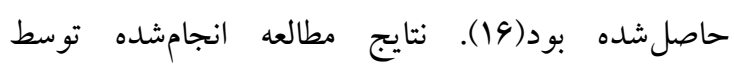
Villanueva SF بود كه در فر آيندهاى UV-C/K حذف در محيط اسيدى بوده و با افزايش pH محيط

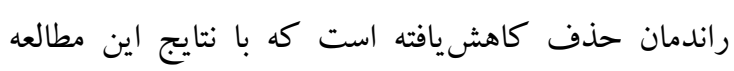

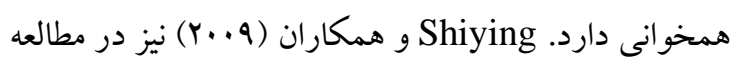

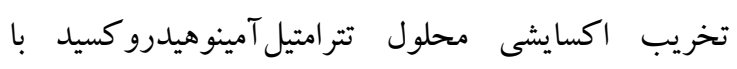

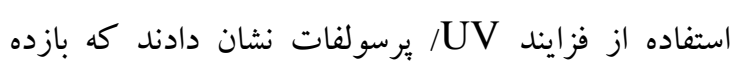

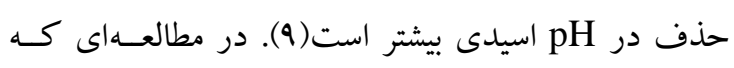

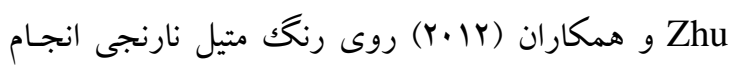

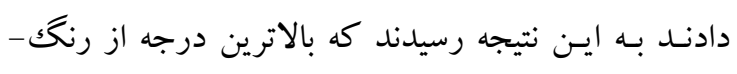

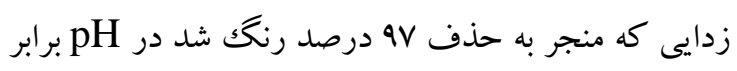

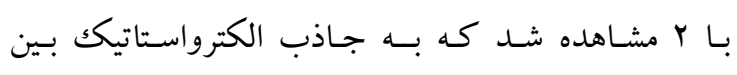
سطح مثبت كاتاليست و آنيون متيل نارنجى نسبت داده

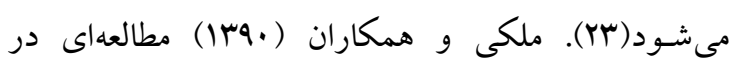

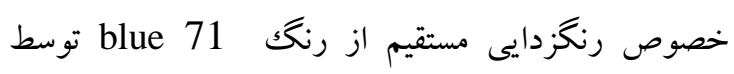

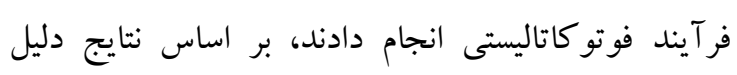

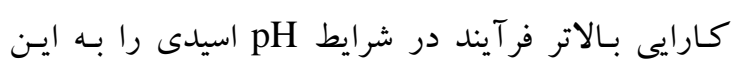
صورت بيـان نمودهاند كه در يكك محيط اسيدى يونهاى روى سطح $\mathrm{H}^{+}$ الكترونهـاى توليدشده مى توانند بهوسيله يونهاى جذبشده و با تشكيل راديكال هيدرو كسيل رنك موجيود

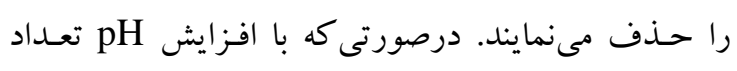

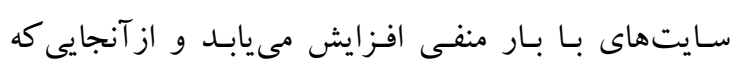

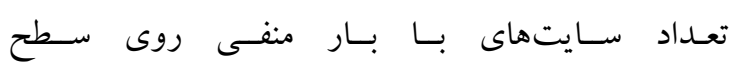

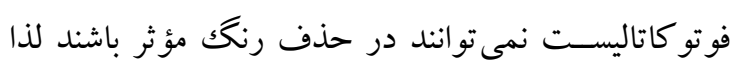


غلظت بيان نموده است و يس از •لهادقيقه واكنش به مرز تعادل رسيده است و راندمان حذف ثابت مانده است(4). با توجه به اينكه در مقدار كربن فعال برابر Y گرم بيشترين ميزان حذف اتفاق افتاد؛ بنابراين دوز كربن فعال برابر Yg/L بهعنوان دوز بهينه در نظر كرفته شد. از ديخر دلايل كاهش حذف رنگ در مقادير بالاى كربن فعال را مىتوان به اشباع شدن سايتهاى فعال كاتاليزور و كاهش ظرفيت آن در طول فرآيند ناشى از افزايش دزاز كربن فعال در حجم و غلظت ثابت محلول باعث نسبت داد.

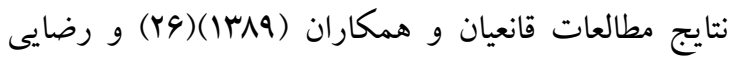
كلانترى و همكاران(سوسו)(Yq) يافتهاى اين مطالعه را تائيد نمودهاند. نتايج مطالعهى Muthirulan و همكاران

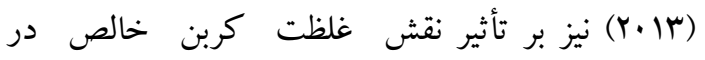
حذف رنكُ آليزارين سيانين سبز از محلولهاى تأكيد نموده است( •r). طبق شكل 4 هرجند رنگك موردمطالعه در حضور يرسولفات بهصورت منفرد و در غياب نور UV حدود

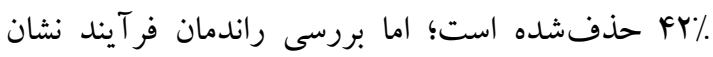
مىدهد كه اين ميزان حذف در مدتزمان واكنش يكسان، نسبت به شرايطى كه از برسولفات در حضور

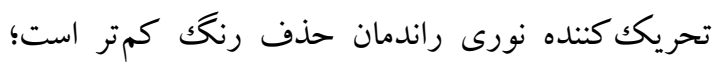
بنابراين مىتوان نتيجه گرفت كه تجزيه فتو كاتاليستى رنگك متيلنبلو درنتيجه حضور توأم يرسولفات و نور UV، در مقايسه با كاربرد مجزاى اين دو عامل بهبوديافته است. علت اين امر را به اين دليل است كه امواج UV به دليل توانايى در توليد مستقيم راديكال يرسولفات در محلول و به تبع آن اكسيداسيون و تغيير ساختار رنگك، مىتواند اثر فر آيند همزمان يرسولفات و كربن فعال گر انوله را افزايش دهد. باوجود محاسن و معايبى كه امواج UV در بحث تصفيه آلايندهها در منابع آبى دارند، نتايج يثوهشها در جند سال اخير نشان داده است كه كاربرد امواج فرابنفش به تنهايى به دليل كارايى كم و نياز به زمان و انرزى زياد محدود است و قابليت استفاده در مقياسهاى بزرگك را ندارد(اس). براى غلبه بر اين مشكل، امواج UV بهصورت
اكسيداسيون بيشرفته بر بايه سولفات جهت حذف دىاتيل فتالات از محلولهاى آبى استفاده كرده بودند، مطابقت دارد(YV). همجنين نتايج بهدست آمده بـا مطالعهى Lin و همكـار انش (r|r) بـر روى حـذف بيس A A بـا فر آيند يرسـولفات فعـالشـده بـهـ روش الكتريكى انجام دادهاند همخوانى دارد در اين مطالعه با افزايش غلظت يرسولفات

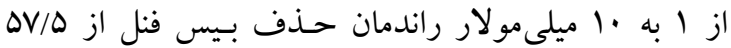
درصد به 99/Y درصد رسيده است ولى با افزايش غلظت

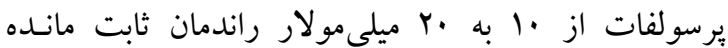

است(Y^).

افزايش درصد حذف متيلنبلو با افزايش دز

كاتاليزور، به دليل افزايش مساحت سطحفعال و و مؤثر در فر آيند حذف و درنتيجه امكان برخورد بيشتر كاتاليز گر با رنگ است. افزايش دوز كاتاليست سبب افزايش تعداد فوتونهاى جذبى شـده و درنتيجه سـبب افزايش تعداد مولكولهاى آلى جذبشـده خواهد شد(YN).

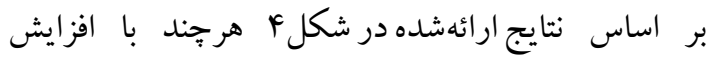

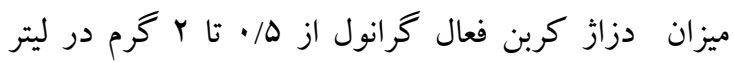
افزايشيافته است؛ اما با افزايش دزاز در مقادير بيش از ب كرم در ليتر كارايى فرآيند در حذف رنگك روند تقريباً ثابتى را داشته است.با افزايش دزاز كربن فعال كرانوله به به دليل غيراشباع ماندن بعضى از سايتهاى فعال آن، ميزان حذف آلاينده كاهش مىيابد. علت كاهش

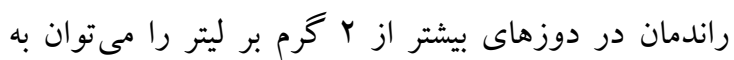
افزايش كدورت محلول و لذا كاهش ميزان نفوذ و يراكندگى نور UV از ســطح كاتاليزگر منتسب نمود. بهاين ترتيب حجـم فعالشده نورى كاهشيافته و درنتيجه مقدار كمى از كربن فعال كرانوله فعال خواهد شد. دليل ديخر را مىتوان به كلوخه شدن و تهنشينى در غلظتهاى بالاى كاتاليز گر نسبت داد مطالعهاى كه توسط مسعودنزاد و همكاران (99 ا) در خصوص حذف رنگك متيلنبلو توسط بركs ZIF-8 صورت گرفت نتايج حاكى از آن است ميزان حذف رنگ با افزايش دوز جاذب تابيش از

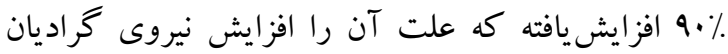


همجِنين اين نتايج با يافتهاى ززارش و و همكاران (Y.・Villanueva

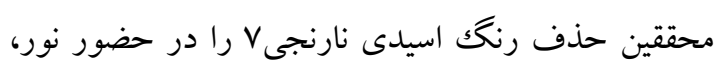

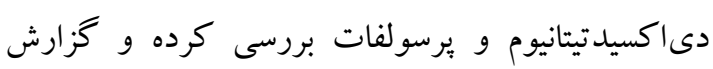

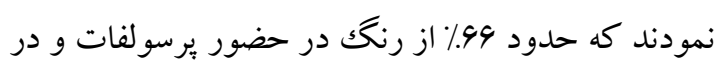

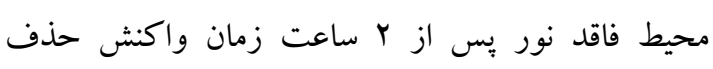

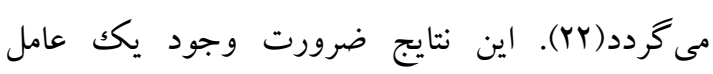
برانخيخته كننده را براى فر آيندهاى فتوشيميايى به اثبات

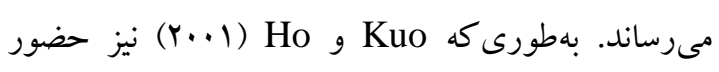

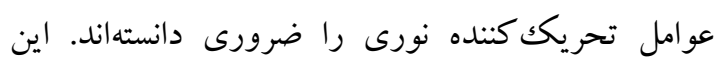

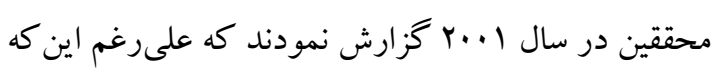

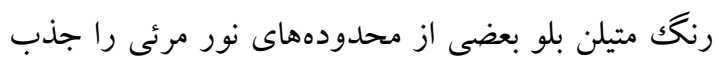

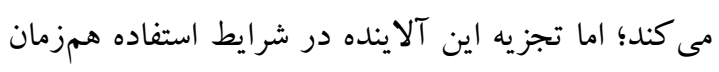
از فتو كاتاليست و يرتو ماوراى بنفش نسبت به به كاربرد

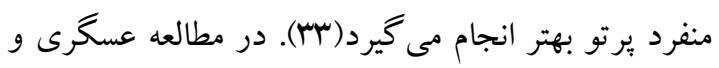

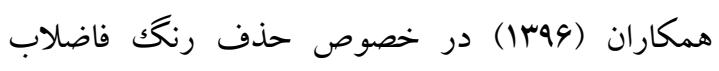
صنايع نساجى توسط فر آيند فتو كاتاليستى دى خداكسيد تيتانيوم

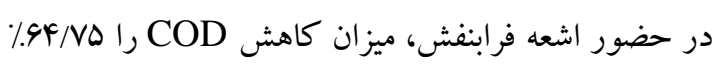

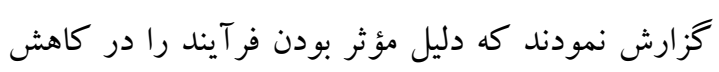

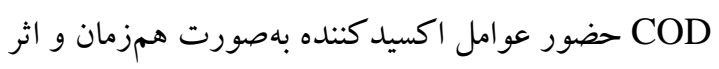
تشديد كندگى آنها از طريق توليد راديكال هيدرو كسيل

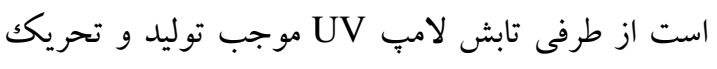
فوتونها به سطح انرزى بالاتر و فعالسازى كاتاليز

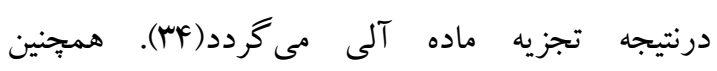

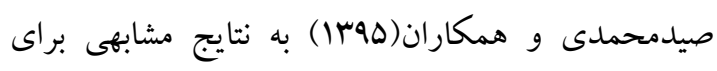

حذف مترونيدازول دست يافتند(ه).

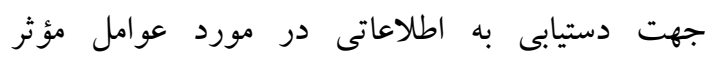

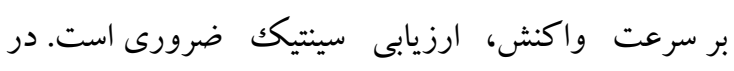
اين مطالعه نمودار در مقابل زمان واكنش رسم كرديد كه ارئي

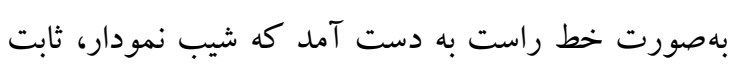

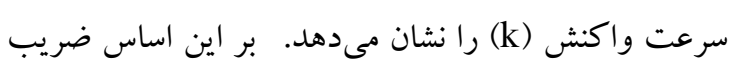

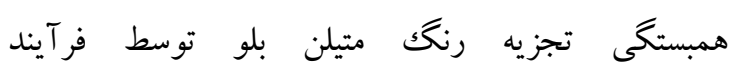
UV/GAC/S $2 \mathrm{O}_{8}$
تر كيبى با فر آيندهاى ديخر نظير UV/ و يا UV/O تركيب با فر آيندهاى الكتروشيميايى مانند

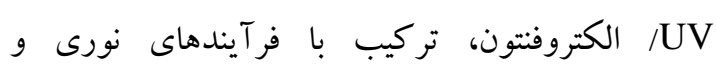

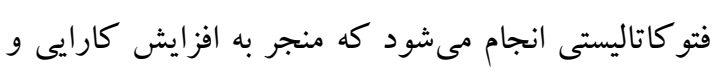

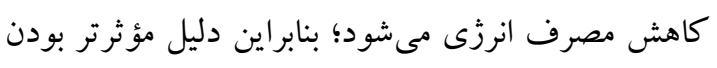

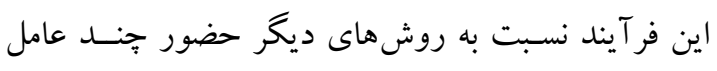

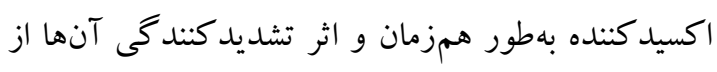

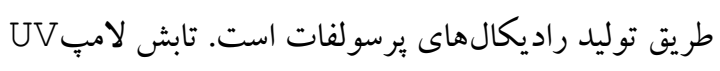
موجب توليد و تحريك فوتونها به سطح انرزى بالاتر و

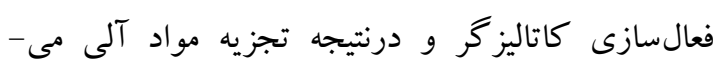

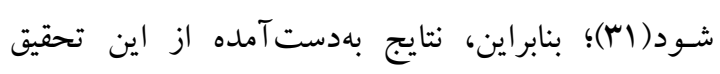

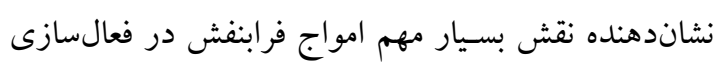

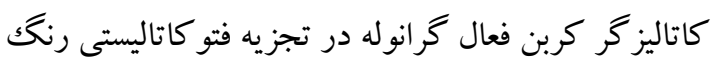

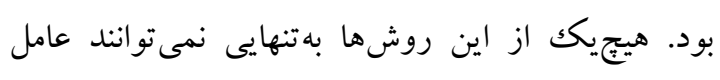

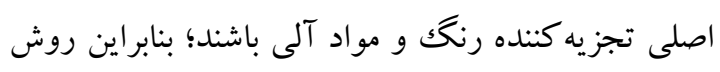

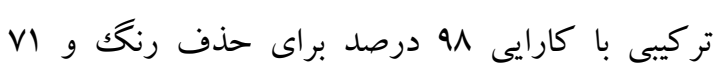
درصد براى كاهش COD مناسب ترين كزينه گزارش كرديد. همجنين مشاهده شد كه مقدار ثابت كربن فعال

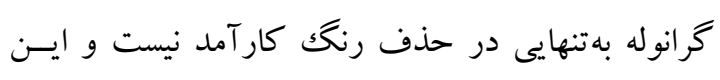

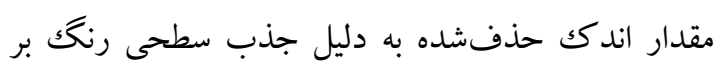
سطح كاتاليست است كه با افزايش زمان تماس، مقدار

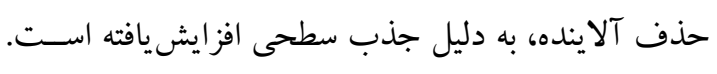
نتايج مشابهى نيز توسط محمودى و همكاران (IMMM (IM) كزارش شده است، بهطورى كه محققان مذكور طى انجام آزمايشهايى بر روى تصفيه فاضلاب نساجى به اين نتيجه

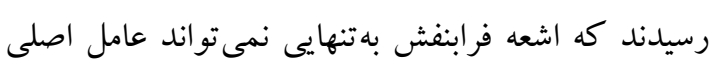

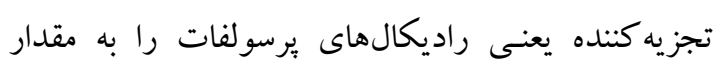

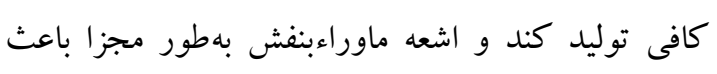

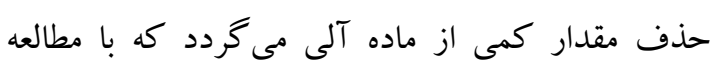

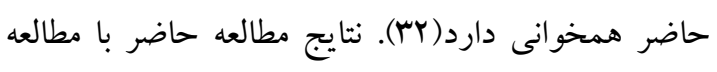

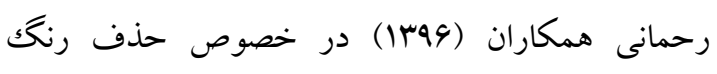

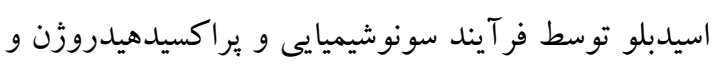
برسولفات فعالشده با آهن فرو مطابقت دارد(19). 
1 4 كارآيى فرآيند بِرسولفات...

استفادهنشده است (سيستم تو أم امواج فرابنفش / برسولفات)

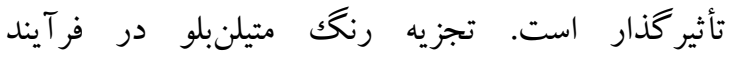
اكسيداسيون موردنظر از واكنش درجه اول تبعيت نموده و ميزان ثابت سرعت واكنش در شرايط بهينه بهرهبردارى وجr/rا است. ميزان كارايى فرآيند در كاهش COD و

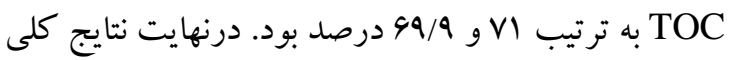
اين مطالعه نشان مىدهد كه فر آيند اكسيداسيون بيشرفته (UV/GAC/S $\left.{ }_{2} \mathrm{O}_{8}\right)$

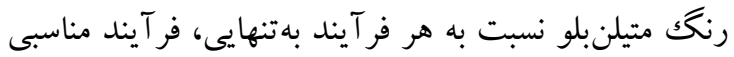

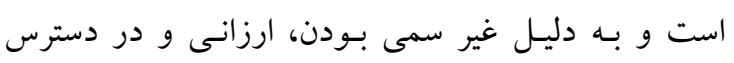

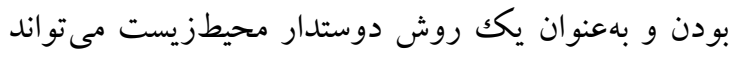

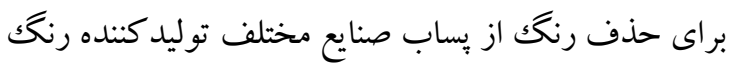

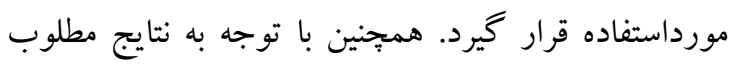
فر آيند فوتو كاتاليستى UV/GAC/S متيلنبلو، مىتوان اظهار داشت كه كارايى فر آيند موردنظر در حذف ساير رنغكها موردبررسى قرار گيرد تا با تعيين دامنه عملكرد اين فر آيند، قابليت استفاده از آن براى تصفيه فاضلابهاى حاوى رنخك هاى مختلف تعيين گردد.

\section{تشكر و قدردانى}

اين مقاله منتج از طرح شماره تحقيقات دانشجويى، دانشگاه علوم يزشكى همدان است.

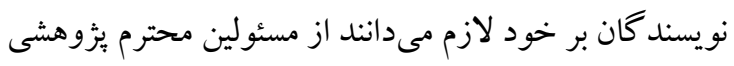
دانشگاه علوم ويزشكى همدان و و كارشناسان محترم

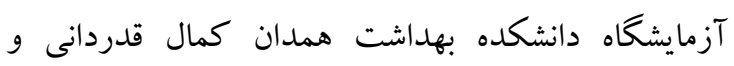

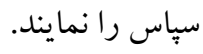

دارد. در اين راستا Amalraj و Pius (F| (r) در بثوهشى

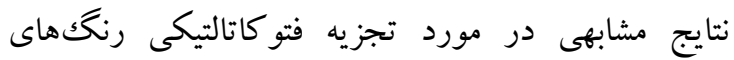
آليزارين با استفاده از

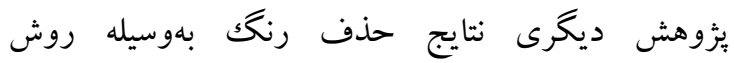
فتو كاتاليستى با استفاده از نانو ذرات ZnO نشاندهنده ييروى فر آيند از مدل سينتيكى مرتبه اول بوده است(rV). بهمنظور بررسى كارايى فرآيند در مقياس محيطى علاوه بر

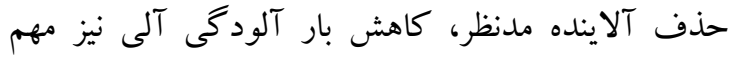
است. آزمايشهاى مختلفى در اين راستا وجود دارد كه تعيين كننده ميزان معدنى سازى فر آيند هستند. از آزمايش-

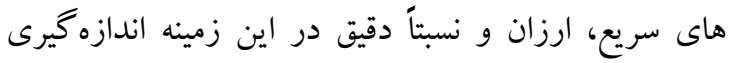
COD است. كاهش COD بيانكر آن است كه طى فر آيند اكسيداسيون فتو كاتاليستى مو ردمطالعه رنخك بهطور كامل به اله

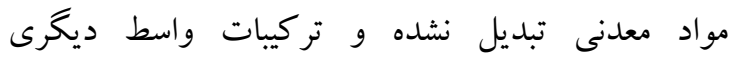
توليدشداند كه مصرف كننده اكسيزن هستند و موجبات افزايش ميزان COD در محلول شدهاند(N).

\section{نتيجه كيرى} اين يثزوهش بهمنظور بر رسى كارئي فر آيند فتو كاتاليستى در

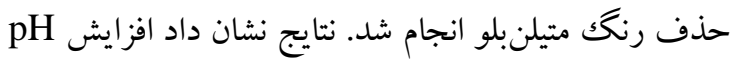
سبب كاهش كارايى فر آيند مىشود، بهطورى كه بيشترين

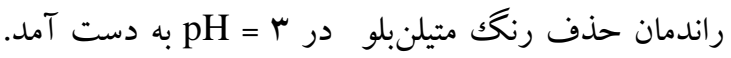
غلظت بهينه آنيون يرسولفات مورداستفاده ا ميلىمولبرليتر بود و با افز ايش آن راندمان حذف كاهش يافت. نقش كربن

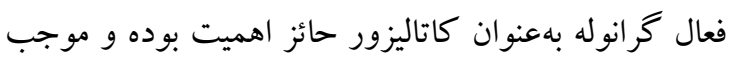
افزايش سرعت فعالسازى يرسولفات شده و درنتيجه در

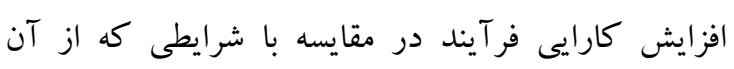

\section{منابع}

1.Asadi F, Dargahi A, Almasi A, Moghofe E. Red Reactive 2 Dye Removal from Aqueous Solutions by Pumice as a Low-Cost and Available Adsorbent. Arch Hyg Sci. 2016;5(3):145152.

2.Jäger I, Hafner C, Schneider K. Mutagenicity of different textile dye products in Salmonella typhimurium and mouse lymphoma cells. Mutat Res. 2004;561(1):35-44.

3.Haghighat GA, Sadeghi S, Saghi MH, Ghadiri SK, Anastopoulos I, Giannakoudakis DA, Colmenares JC, Shams M. Zeolitic imidazolate frameworks (ZIFs) of various morphologies 
against eriochrome black-T (EBT): optimizing the key physicochemical features by process modeling. Colloids Surf A. 2020;606:125391.

4. Ahmadi E, Gholami M, Farzadkia M, Nabizadeh R, Esrafili A, Azari A. Evaluation of Diethyl phthalate and Diallyl phthalate biodegradation mechanisms in the treatment of synthetic wastewater. J Health in the Field. 2017;2(1). [In persian]

5.Wu J, Zhang H, Qiu J. Degradation of Acid Orange 7 in aqueous solution by a novel electro/ $/ \mathrm{Fe}^{2+} /$ peroxydisulfate process. J Hazard Mater. 2012;215:138-45.

6.Massoudinejad M, Mohammadi A, Sadeghi S, Ghaderpoori M, Sahebi S, Alinejad A. Arsenic adsorption over dodecahedra ZIF-8 from solution aqueous: modelling, isotherms, kinetics and thermodynamics. Int J Environ Anal Chem. 2020:1-7.

7.Al-Momani F, Touraud E, Degorce-Dumas J, Roussy J, Thomas O. Biodegradability enhancement of textile dyes and textile wastewater by VUV photolysis. J Photoch Photobio A. 2002;153(1-3):191-7.

8. Hossieni S, Sadeghi S, Saghi MH, Ghadiri SK. Evaluation of photocatalytic process using $\mathrm{GO} / \mathrm{ZnO}$ nanocomposites under LED irradiation for removal of Endocrine Disrupting Chemicals (EDCs) from aqueous solutions. SJKU. 2019;24(4). [In persian]

9.Shiying Y, Ping W, Xin Y, Guang W, Zhang W, Liang S. A novel advanced oxidation process to degrade organic pollutants in wastewater: Microwave-activated persulfate oxidation. J Environ Sci. 2009;21(9):1175-1180.

10.Zhang M, Chen X, Zhou H, Murugananthan M, Zhang Y. Degradation of p-nitrophenol by heat and metal ions co-activated persulfate. Chem Eng Sci. 2015;264:39-47.

11.Alinejad A, Sadeghi S, Ghaderpoori M, Sahebi S, Ghaderpoury A, Mohammadi AA, Saghi MH, Gholampour Y, Khani Jeihooni A. High adsorption of methylene blue from aqueous solutions using leaf-shaped ZIF-8. Int J Environ Anal Chem. 2019; 19:1-4.

12.Lei L, Gu L, Zhang X, Su Y. Catalytic oxidation of highly concentrated real industrial wastewater by integrated ozone and activated carbon. Appl Catal A-Gen. 2007;327(2):28794.

13.Liu F, Yi P, Wang X, Gao H, Zhang H. Degradation of Acid Orange 7 by an ultrasound/ZnO-GAC/persulfate process. Sep Purif Technol. 2018;194:181-7.

14. Awwa A. Wef. Standard Methods for the Examination of Water \& Wastewater, 21st ed, American Public Health Association 2005;23.

15.Seidmohammadi A, Bahrami M, Omari S, Asadi F. Removal of Cephalexin From Aqueous Solutions Using Magnesium Oxide/Granular Activated Carbon Hybrid Photocatalytic Process. Avicenna J Environ Health Eng. 2019;6(1):24-32.

16.Rahmani A, Asgari G, Leili M, Aazami Gilan R. Degradation of Methylene Blue Dye Using Fenton/PhotoFenton-Peracetic Acid (UV/Fe3+-CH3COOH- $\mathrm{H}_{2} \mathrm{O} 2$ ) Processes from Aqueous Solutions. JMUMS. 2017;27(153):95-111. [In persian]

17.Zhang X, Zhang L, Hou L, Dong L, editors. Persulfate-enhanced Photocatalytic Degradation of Methylene Blue. 2016 5th International Conference on Sustainable Energy and Environment Engineering (ICSEEE 2016); 2016: Atlantis Press.

18.Son G, Lee H. Methylene blue removal by submerged plasma irradiation system in the presence of persulfate. Environ Sci Pollut Res. 2016;23(15):15651-6.

19. Ghauch A, Tuqan AM, Kibbi N, Geryes S. Methylene blue discoloration by heated persulfate in aqueous solution. Chem Eng J. 2012;213:259-71.

20.Mohamed MM, Al-Esaimi MM. Characterization, adsorption and photocatalytic activity of vanadium-doped $\mathrm{TiO} 2$ and sulfated $\mathrm{TiO} 2$ (rutile) catalysts: degradation of methylene blue dye. J Mol Catal. 2006;255(1-2):53-61. 
Vارآيَ فرآيند برسولفات... V.

21.Hung CM, Chen CW, Liu YY, Dong CD. Decolorization of methylene blue by persulfate activated with $\mathrm{FeO}$ magnetic particles. Water Environ Res. 2016;88(8):675-86.

22.Villanueva $\mathrm{S}$, Martİnez S. TiO2-assisted degradation of acid orange 7 textile dye under solar light. Sol Energy Mater Sol Cells. 2007;91:1492-5.

23.Zhu H, Jiang R, Fu Y, Guan Y, Yao J, Xiao L, et al. Effective photocatalytic decolorization of methyl orange utilizing $\mathrm{TiO} 2 / \mathrm{ZnO} /$ chitosan nanocomposite films under simulated solar irradiation. Desalination. 2012;286:41-8.

24.Maleki A, Mahvi AH, Shahmoradi B. Hydroxyl radical-based processes for decolourization of direct blue 71: A comparative study. Asian J Chem. 2011;23(10):411. [In persian]

25.Portjanskaja E, Preis S. Aqueous photocatalytic oxidation of lignin: the influence of mineral admixtures. Int J Photoenergy. 2007;2007.

26.Ghaneian M, Ehrampoush M, Ghanizadeh G, Dehvary M, Abootoraby M, Jasemizad T. Application of solar irradiation/K2S2O8 photochemical oxidation process for the Removal of reactive blue 19 dye fromaqueous solutions. IJHE. 2010;3(2):165-176.

27.Esrafili A, Rezaei Kalantary R, Azari A, Ahmadi E, Gholami M. Removal of diethyl phthalate from aqueous solution using persulfate-based (UV/Na2S2O8/Fe2+) advanced oxidation process. JMUMS. 2016;25(132):122-135.[In persian]

28.Lin H, Wu J, Zhang H. Degradation of bisphenol A in aqueous solution by a novel electro/ $\mathrm{Fe}^{3+} /$ peroxydisulfate process. Sep Purif Technol. 2013;117:18-23.

29.RezaeiKalantary R, JonidiJafari A, Kakavandi B, Nasseri S, Ameri A, Azari A. Adsorption and magnetic separation of lead from synthetic wastewater using carbon/iron oxide nanoparticles composite. JMUMS. 2014;24(113):172-183.[In persian]

30.Muthirulan P, Meenakshisundararam M, Kannan N. Beneficial role of ZnO photocatalyst supported with porous activated carbon for the mineralization of alizarin cyanin green dye in aqueous solution. J Adv Res. 2013;4(6):479-84.

31.Kordkandi SA, Forouzesh M. Application of full factorial design for methylene blue dye removal using heat-activated persulfate oxidation. $J$ Taiwan Inst Chem Eng. 2014;45(5):2597-604.

32.Mahmoodi NM, Arami M. Degradation and toxicity reduction of textile wastewater using immobilized titania nanophotocatalysis. J. Photochem. Photobiol. B, Biol. 2009;94(1):20-4.

33.Kuo W, Ho P. Solar photocatalytic decolorization of methylene blue in water. Chemosphere. 2001;45(1):77-83.

34.Asgari G, Seidmohammadi A, Bagheri M, Chavoshi S. Evaluating the efficiency of dye removal from textile industry wastewater using the titanium dioxide photocatalytic process under UV-LED light irradiation: A case study, Hamadan Nakh Rang Factory. Avicenna J Clin Med. 2017;24(2):143-51.

35.Seidmohammadi A, Asgari G, Torabi L. Removal of metronidazole using ozone activated persulfate from aqua solutions in presence of ultrasound. JMUMS. 2016;26(143):160-73.[In persian]

36.Amalraj A, Pius A. Photocatalytic degradation of alizarin red $\mathrm{S}$ and bismarck brown $\mathrm{R}$ using TiO2 photocatalyst. J Chem Appl Biochem. 2014;1(1):1-7.

37.Behnajady M, Modirshahla N, Hamzavi R. Kinetic study on photocatalytic degradation of CI Acid Yellow 23 by ZnO photocatalyst. J Hazard Mater. 2006;133(1-3):226-32.

38.Gu L, Wang J, Zou Z, Han X. Graphitic-C3N4-hybridized TiO2 nanosheets with reactive $\left\{\begin{array}{lll}0 & 0 & 1\end{array}\right\}$ facets to enhance the UV-and visible-light photocatalytic activity. J Hazard Mater. 2014;268:216-23. 